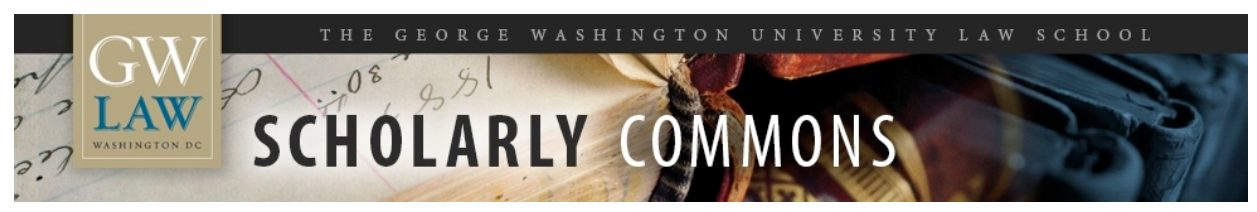

\title{
The Sarbanes-Oxley Yawn: Heavy Rhetoric, Light Reform (And it Might Just Work)
}

Lawrence A. Cunningham

George Washington University Law School, lacunningham@law.gwu.edu

Follow this and additional works at: https://scholarship.law.gwu.edu/faculty_publications

Part of the Law Commons

\section{Recommended Citation}

Lawrence A. Cunningham, The Sarbanes-Oxley Yawn: Heavy Rhetoric, Light Reform (And it Might Just Work), 35 Conn. L. Rev. 915 (2003).

This Article is brought to you for free and open access by the Faculty Scholarship at Scholarly Commons. It has been accepted for inclusion in GW Law Faculty Publications \& Other Works by an authorized administrator of Scholarly Commons. For more information, please contact spagel@law.gwu.edu. 


\title{
The Sarbanes-Oxley Yawn: Heavy Rhetoric, Light Reform (And It Might Just Work)
}

\author{
Lawrence A. Cunningham \\ Boston College Law School \\ [Please cite as forthcoming 36 U. Conn. L. Rev. (2003)]
}

Draft: October 2002

This paper can be downloaded without charge from the

Social Science Research Network:

http://ssrn.com/abstract_id $=337280$ 


\title{
The Sarbanes-Oxley Yawn: Heavy Rhetoric, Light Reform (And It Might Just Work)
}

\author{
Lawrence A. Cunningham * \\ [Please cite as forthcoming 36 U. Conn. L. Rev. (2003)] \\ [Preliminary Draft; Comments Sought]
}

Facing a series of accounting and corporate governance scandals from Enron Corp. to WorldCom Inc. at the dawn of the new millennium, Congress possessed that rare political and institutional capacity to address deep causes and systemic dysfunction. ${ }^{1}$ Congress used this episodic power opportunity to enact the Sarbanes-Oxley Act of $2002 .^{2}$ On signing it, conservative Republican President George W. Bush said it boasted "the most far-reaching reforms of American business practices since the time of Franklin Delano Roosevelt." Recentlyappointed SEC Commissioner Harvey Goldschmid, a liberal Democrat, called the Act the "most sweeping reform since the Depression-era securities laws. ${ }^{4}$ Other participants and observers sang the same song, routinely describing the Act as "sweeping reform."

A soberly apolitical view sees the Act as more sweep than reform. The Act's "farreaching" characteristic is commandeering nine studies to examine the possible causes of perceived system breakdown. ${ }^{6}$ Studies range from reassessing the fundamental philosophy of

* Professor of Law and Business, Boston College. (C) 2002. All rights reserved. E-mail: Lawrence.Cunningham@BC.edu.

${ }^{1}$ E.g., Roberta S. Karmel, Securities Regulation: A New Watchdog for Public Accountants, N.Y.L.J., (Aug. 15, 2002) ("The enormity of the scandals, the extent of the losses to shareholders and employees of the companies affected, not only of their jobs but also of their pensions, and the prospects of an election in a few months of a Congress now split fairly evenly between Republicans and Democrats made it difficult for the accounting profession to resist reforms that the Securities and Exchange Commission (SEC) has considered making for a long time.").

2107 Pub. L. No. 204, 116 Stat. 745 (hereinafter, "the Act"). The President signed the Act July 30, 2002, following votes of 99-0 in the Senate and 423-3 in the House.

3 Elisabeth Bumiller, Bush Signs Bill Aimed at Fraud In Corporations, N.Y.Times (July 31, 2002).

${ }_{5}^{4}$ Shanon D. Murray, Is SEC Ready for Its Own Sweeping Changes?, N.Y.L.J. (Aug. 29, 2002).

${ }^{5}$ Scores of news stories used the phrase "sweeping reform" and compared the Act, using the same words its champions did, to the New Deal era's enactment of the original securities laws, the Securities Act of 1933 and the Securities Exchange Act of 1934. Some offered even more extreme characterizations, which tended to rise in proportion to the level of parochial interest one held in the Act's contents: the head of the AICPA said the Act "contains some of the most far-reaching changes that Congress has ever introduced to the business world." Barry C. Melancon, A New Accounting Culture (Sept. 4, 2002), www.aicpa.org; see also Chuck Landes, The Sarbanes-Oxley Act of 2002, In Our Opinion (The Newsletter of the AICPA's Audit and Attest Standards Group) (July 2002), at 5 (chair of the group calling the Act "the most significant legislation affecting the accounting profession since 1933"), htp://www.aicpa.org.

6 Nearly every vocal source had an interest in characterizing the Act as "sweeping reform," politicians on the right to stem further regulation and win votes, politicians on the left to brag and win votes, lawyers to attract clients, media to gain audience, bankers to get deal flow back on 
US accounting standards to researching the roles of professional gatekeepers in securities markets and frauds, and investment banking firms in financial reporting and frauds. In addition to punting to those nine studies, the Act's main provisions are stunts to promote investor confidence. ${ }^{7}$ The most prominent example was the essentially redundant but much publicized requirement for top executives to certify financial statements filed with the Securities and Exchange Commission. ${ }^{8}$

Apart from sweeping punts and stunts, the Act reenacts in a new federal guise more than a dozen existing federal regulations, state laws, stock exchange and securities industry rules, accounting or auditing practices, and corporate governance norms. ${ }^{9}$ These codifications do little more than shine a spotlight on some "best practices," an important function but hardly "reform" of any sort, "sweeping" or otherwise. ${ }^{10}$ Incremental provisions of the Act are best seen as patchwork responses to precise transgressions present in the popularized scandals, legislative

track amid a severe downturn, and even managers to boost investor confidence. Possible exceptions to this incentive are executives of foreign corporations, most of whom regarded the Act as a yawn, see infra, though some bridled at the suggestion that the US was, once again or still, trying to regulate the world. See Lawrence A. Cunningham, Sarbanes-Oxley and the Rest of the World (manuscript, forthcoming in 29 N.C. J. Intl. L. \& Comm. Reg. (2003)). Plaintiffs' securities lawyers are another possible exception. E.g., William S. Lerach, The Chickens Have Come Home to Roost, at 16 (speech, July 2002) (characterizing the reforms as "very modest indeed") (copy on file with the author). Some other moderate voices were heard as well. E.g., David J. Sorin, Kristina K. Pappa \& Emilio Ragosa, Sarbanes-Oxley Act: Politics or Reform? Statute's Effects Are Not as Profound as Legislators Would Have Us Believe, N.J.L.J. (Sept. 2, 2002). These lawyers, of Hale \& Door's Princeton office, observe that a literal reading of the Act suggests great reform accomplishment, while the practical effects are not profound but merely a mandate to comply with customary practices.

7 To give one example at the outset, where the Act puts confidence ahead of it being earned, the Act directs the SEC (or stock exchanges at its direction) to adopt rules addressing securities analyst conflicts of interest, "including rules designed to foster greater public confidence in securities research.” Act, §501 (amending 15 U.S.C. §780-6). Rules intended to build confidence are sandcastles without the prior building of a basis of justification for reposing that confidence. The sentiment should have been expressed as "including rules designed to promote the integrity of securities research warranting greater public confidence."

817 C.F.R. 240.12-b11(b). See infra text accompanying notes xx-xx.

9 A little history of business evolution and reform in $20^{\text {th }}$ century America would have suggested a more qualified view of the Act than that widely indulged. See Appendix A. Even if "far-reaching" and "sweeping" are accurate in a raw sense, many "reforms" since the New Deal are at least or more so, particularly 1977's Foreign Corrupt Practices Act, reacting to that era's corporate scandals. See infra. The leaders thus "protest too much," particularly our first President to hold an MBA (his from Harvard University) and an SEC Commissioner who was a long-time professor of corporate law (at Columbia University School of Law).

${ }^{10}$ In keeping with the political punt-and-stunt view of the Act, note that applying adjectives such as "sweeping" and "far-reaching" to nouns such as "reforms" draws emphasis to the adjectives, more exciting terms, muting the noun. It gives a speaker confidence in his fidelity to emphasize the adjective ("sweeping", which the Act's breadth may be) by de-emphasizing the noun ("reforms," which the Act barely contains). 
action akin to the frequently maligned military strategist fighting the last war rather than planning for the next. The Act's only manifest boldness is in upping the ante for financial fraud, heightening fines and jail terms for perpetrators and broadening enforcement mechanisms. ${ }^{11}$

The Act is far from trivial, however. Though mostly patchwork and codifying, there are a couple of moves amounting to legislative silver bullets-still not sweeping reform but potentially profound. The principal silver bullet relates to the structure and funding of those who set the standards for auditing and accounting in the United States. Stripped of power to make authoritative auditing standards is the American Institute of Certified Public Accountants (AICPA), the industry body having since 1939 defined generally accepted auditing standards (GAAS). ${ }^{12}$ It is replaced by a Public Company Accounting Oversight Board (PCAOB) to be funded instead by public companies and led by mostly non-CPAs. Implicitly restructured is the Financial Accounting Standards Board (FASB), the leading U.S. promulgator since 1973 of generally accepted accounting principles (GAAP). No longer will it be so recognized, unless its funding is provided by public companies rather than the accounting profession and it satisfies other membership and procedural requirements designed to distance it from the profession.

Beyond these silver bullets, in this view, the Act is best described as entangling, ${ }^{13}$ enshrining detailed rules as federal law and easing the burden of those policing corporate misconduct. ${ }^{14}$ Besides enlarging the enforcer's net and mandating studies, the Act makes no direct effort to exhort, encourage, or command superior accounting or corporate governance. The Act can be seen as "sweeping" in the modest sense of the number of disparate issues and groups singled out for explicit or implicit blame in the agitation prompting it. Nearly every

${ }^{11}$ Contemporaneously with the Act, the New York Stock Exchange surfaced its own new rules on auditing, corporate governance and disclosure, all of which go further than the Act yet were given virtually no fanfare and in any event are not sweeping reforms either. See Martin Lipton \& Laura A. McIntosh, Corporate Governance in Light of Sarbanes-Oxley and the NYSE Rules, $M \& A$ Lawyer (Sept. 2002), at 8 (discussing the Act and the new NYSE rules together and saying, following the common refrain, they "impose wide-ranging new requirements" and "raised the bar"- then acknowledging that "there is no change in the fundamental legal principles applicable to the duties and responsibilities of boards of directors, [but] there is a clear change in attitude").

12 The AICPA was in turn overseen by the Public Oversight Board, a body it funded and which disbanded itself in January 2002 amid SEC indications that the SEC sought a new independent oversight body. See Associated Press, Oversight Board Votes to Disband, Citing SEC Plan, Chicago Trib. (Jan. 24, 2002).

13 See Simon Lorne, Sarbanes-Oxley: The Pernicious Beginnings of Usurpation?, Wall St. L. (Sept. 2002) (the Act is "an unusual, and awkward, aggregation of legislative measures" that "adds to what can be a suffocatingly complex regulatory environment").

14 It will generate "sweeping" new legal business. See Anthony Lin, Corporate Governance Practice Groups Spawn From Troubled Waters, N.Y.L.J., Aug. 12, 2002 (noting common practice among law firms in Act's wake to write client memos outlining issues and inviting clients to call and noting this is "hardly surprising" given that the Act and its provisions "promise law firms something for just about everyone, and for a long time to come"). In this sense the Act is akin to the original securities acts, and a sense in which "sweeping" is an accurate description, justifying comparison to the 1930s Acts. 
remotely responsible group but one is designated for study or regulation (though hardly "reform"):

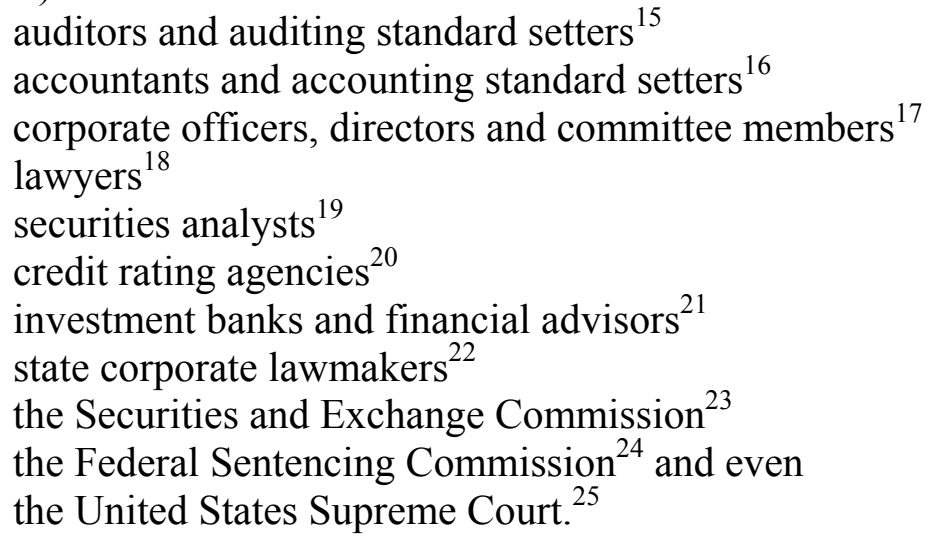

15 See, e..g., Act $\S \S 101-105$ (establishing and specifying operation of a new Public Company Accounting Oversight Board); $\S \S 201-204$ (non-audit services, audit partner rotation, reports to audit committees); see infra text accompany notes $\mathrm{xx}-\mathrm{xx}$.

16 See, e..g., Act $\S \S 108-109$ (establishing funding and procedural mechanisms for bodies wishing to contribute to establishing generally accepted accounting standards); see infra text accompany notes $\mathrm{xx}-\mathrm{xx}$.

17 See, e..g., Act $\S \S 301-306$ (audit committee duties, financial report certifications, influencing auditors, forfeiting bonuses, insider trade disclosure, blackouts on trading); Act $\S \S 402,404,406$, 407 (loans, internal controls, ethics codes, financial expert on audit committee); see infra text accompany notes $\mathrm{xx}-\mathrm{xx}$.

18 See Act $\S 307$ (directing SEC to establish minimum rules of professional responsibility for lawyers involved with it, including concerning reporting evidence of wrongdoing at SEC registrants); see infra text accompany notes $\mathrm{xx}-\mathrm{xx}$.

19 See Act $\S 501$ (directing SEC to establish rules governing securities analysts relating to numerous matters of timing, disclosure, and conflicts of interest); see infra text accompany notes $\mathrm{xX}-\mathrm{xx}$.

${ }^{20}$ See Act $\S 702$ (directing SEC to study role and importance of credit rating agencies and accuracy of their appraisals); see infra text accompany notes xx-xx.

21 See Act $\S 705$ (directing Comptroller to study role of investment banks and financial advisors in the collapse of Enron and failure of WorldCom and more generally in producing misleading financial statements); see infra text accompany notes $\mathrm{xx}-\mathrm{xx}$.

22 See, e.g. Act $\S \S 306,402$ (authorizing federalized derivative lawsuits to recover profits generated in violation of new blackout rules, prohibiting loans to officers and directors); see infra text accompany notes xx-xx.

23 See, e.g., Act $\S 408$ (requiring "enhanced" review of periodic filings); see infra text accompany notes $\mathrm{xx}-\mathrm{xx}$.

${ }^{24}$ See, e.g., Act $\S \S 805,905,1104$ (directing Federal Sentencing Commission to review elements of its guidelines to assure, among other things, they reflect the seriousness of financial crimes); see infra text accompany notes $\mathrm{xx}-\mathrm{xx}$.

${ }^{25}$ E.g., Act $\$ 703$ (directing SEC to study aiding and abetting violations that go unsanctioned, a direct inquiry concerning the consequences of Bank of Denver); see infra text accompany notes $\mathrm{xx}-\mathrm{xx}$. 
Missing from the list of blameworthy agents is Congress itself, for the Act nowhere addresses Congress's recent major relevant and potentially responsible changes, such as the Private Securities Litigation Reform Act of 1995 (PLSRA), ${ }^{26}$ the Securities Litigation Uniform Standards Act of 1998 (SLUSA), ${ }^{27}$ or the substantial repeal of the Banking Act of 1933 (GlassSteagall) by the Gramm-Leach-Bliley Financial Modernization Act of $1999 .{ }^{28}$ On the contrary, the Act's bulk beefs up internal controls and processes initially created in an Act of Congress in 1977's Foreign Corrupt Practices Act (FCPA).

Authentically "far-reaching" and "sweeping" "reform" would have provoked Congressional self-examination, especially reassessment of such acts. One issue is whether the process and control philosophy of the FCPA followed in the Act is adequate or should broader substantive reform be preferred. Another is whether the relaxation of constraints of the PLSRA/SLUSA and Glass-Steagall repeal have proven optimal. Other possibilities not pursued in the Act include boldness such as rendering accounting standards as law or giving corporate fiduciary obligation teeth. ${ }^{29}$ The Act approaches nothing of the kind. ${ }^{30}$

This reading of the Act as modest is advanced in three stages of this Article. The first sets the background by summarizing the salient features of the dominant precipitating scandals and their times. The second stage dissects every material provision of the Act in context. ${ }^{31}$ The third and final stage suggests why the political rhetoric and substance diverged so widely, with illustrations of what a substantively bold Act might have looked like.

Explaining the Act's rhetoric-reality yawn requires speculation but informed hunches readily emerge. On the one hand, Congress may have understood that the visible debacles did not show chronic epidemics but discrete pathologies and their root causes were market psychology beyond its regulatory reach (hence a reform-less Act). On the other, Congress knew that the public perceived an acute systemic crisis of power abuse they had no responsibility for creating (hence the "sweeping" rhetoric). Another explanation, which also explains the Act's call

${ }^{26}$ Private Securities Litigation Reform Act of 1995, Pub. L. No. 104-67, 109 Stat. 737, 758 codified as amended at 15 U.S.C.A. $78 u-4$ (West 1997 and Supp. 2000)).

${ }^{27}$ Securities Litigation Uniform Standards Act of 1998, Pub. L. No. 105-353, 112 Stat. 3227 codified at 15 U.S.C.A. 77p (West 1997 \& Supp. 2000), 78bb(f) (West Supp. 2000)).

2812 U.S.C. $\S 1843(\mathrm{c})(3),(\mathrm{k})(1)$ (Supp. V 1999) (repeal of Glass-Steagall is codified at 12 U.S.C. § 24 (1994 \& Supp. II 1997); 12 U.S.C. §§ 78, 377 (1994), repealed by 12 U.S.C. § 1843 (Supp.V 1999); 12 U.S.C. $§ 378$ (1994)). The Act's required study of the role of investment banks in financial reporting (Act, $\S 705$ ) could bear on the wisdom of Congressional reduction of the barriers between the banking and securities industries but the context and texture of the provision seems directed more narrowly at inherent culpability than structural causes. See infra text accompany notes $\mathrm{xx}-\mathrm{xx}$.

${ }^{29}$ See infra Part III.

30 Absence of self-direction in the Act may be a natural product of a legislative body's process. Congress can always (with the right political atmosphere) undertake self-examination without directive legislation. If Congress wants to direct or countermand others, formal action is necessary. Apart from the directed studies, however, the Act gives no suggestion that Congress is reexamining its own previous "sweeping reforms."

${ }^{31}$ In that sense, this Article is as sweeping as the Act. Some subjects, touched on by the Act and assessed here, open up such deep and broad issues to warrant an entire law review article devoted to analyzing each. Undoubtedly, those will come; this Article's sweep is more modest. 
for so many studies, is that it is too soon to diagnose deep causes or broad shortcomings but that immediate action was politically expedient. The studies bridge the gap between action and knowledge, constituting continuing threats to their targets to abide by the spirit of the Act, a threat to make the "sweeping" rhetoric real "reform."

\section{The Backdrop}

The Sarbanes-Oxley Act must be understood in context. It followed against the backdrop of the telecom/dot.com-infused bubble of the late 1990s, featuring new and much misunderstood companies. The history of that era will be written many times from numerous perspectives with scope far beyond that possible or necessary to establish sufficient background to understand the climate in which the Act was adopted. A few angles on the environment are offered in a brief overview, beginning with broader financial trends, highlighting the four galvanizing corporate debacles, and finishing with a sense of the regulatory landscape leading up to the Act. ${ }^{32}$

\section{A. Events}

The late 1990s was a period of economic expansion and technological innovation of a magnitude that comes once a generation in American business history. Extraordinary change was led by the exploitation of technologies enabling the widespread use of the Internet and proliferation of telecom infrastructure. To give one practical illustration of the sea change, in 1996 hardly anyone used email and a minority used cell phones; by 2000, nearly everyone used both regularly.

Heady financial times such as these invariably draw to investing millions of people who lack business knowledge and to business thousands of people who lack moral scruples. The combination produces and sustains exaggeration of the real achievements and obfuscation of the setbacks. With flushness fueling financial fantasies, accounting and corporate governance become at worst obstacles to overcome, at best technical burdens to meet as painlessly as possible, not tools to promote quality financial reporting or disciplined management oversight. The spirit of the times overcomes the spirit of the rules.

The hallucinations of the late 1990s began to end in March 2000, when investors recognized that a financial bubble had arisen and drove stock market indexes plunging immediately and stagnating for months. ${ }^{33}$ A year and half later, terrorist attacks on September 11,2001 jolted markets and caused enormous economic and political uncertainties. ${ }^{34}$ US saberrattling concerning threats to invade Iraq and topple its leadership kept nerves unsteady, an unease that would continue for at least a year.

The unraveling of Enron Corp., a direct product of the era's financial fantasia, began in late 2001 and escalated in early 2002, heightening already high marketplace anxiety. Even then, however, investors held on, markets held sideways, and politicians began hearings but kept them on the sidelines. In those early days of the forthcoming domino process, President George W.

32 This account is not intended to pass as history or as remotely complete. Undoubtedly left out are events, companies, and regulatory developments essential for a full understanding of the period. For purposes of setting the stage on which the Act arose, however, the highlights given should be sufficient.

33 All market indexes began to fall dramatically during that month, including the Nasdaq and the Dow Jones Industrial Average.

34 The New York Stock Exchange closed for a week. When it reopened equities steadied or saw modest gains, but in ensuing months a sell off of increasing proportions continued for more than a year. 
Bush was able, with some credibility, to attribute the Enron debacle to a few rotten apples. Other Republicans likewise showed no inclination toward a regulatory response.

As the Enron shenanigans unfolded, the number of obvious rotten apples at the company increased. Also, the number of rotten apples at professional service firms that participated with or aided those apples soared. The brightest spotlight was shone on Enron's outside auditing firm, Arthur Andersen. As the heat bore down on that firm, its employees raced to destroy evidence of wrongdoing, alter records, and engage in other felonious acts obstructing justice. The results were client flight, a criminal jury verdict, more client flight, and ultimate dissolution. At this stage, the debacles of Enron and Arthur Andersen provoked public disgust, Congressional hearings and more than 40 reform bills mostly directed at auditor oversight, but they were put on the back burner. ${ }^{35}$

An accounting meltdown at Global Crossing, Ltd. began to tip the dominos. Dubious financial reporting concerning a wide range of practices and policies surfaced at the telecom industry's darling, just as the Enron disclosures were widening. This was the beginning of the end for Global Crossing and its industry cohorts, as the company sailed toward bankruptcy. Even so, while Democrats in Congress eagerly stepped up hearings, hauled executives and professionals before them, and drafted reform proposals, a substantial chance remained that the upheavals would fade into the recesses of public memory without call for formal political action. ${ }^{36}$

But there was more. A wave of reported corporate debacles mounted pressure to respond in Spring 2002. These were characterized by distinctly different kinds of misbehavior. For example, the widely-publicized cases concerning Adelphia Communications Corp. and Tyco International Ltd. involved corporate loans to executives on sweetheart terms. These were stories of corporate greed, not in any direct sense accounting corruption of the type practiced at Enron or Global Crossing. ${ }^{37}$

Other stories involving accounting corruption that had been in the background of the news for years, now became front-page newspaper reports and feature stories on broadcast and cable television shows. Companies included household names such as AOL Time Warner Inc. Rite Aid Corp. and Xerox Corp. The parade of disparate tales of illicit activity was extended and likewise coverage-saturated by events concerning ImClone Systems Inc. The biotech company's CEO allegedly told his father and daughter, and perhaps home furnishings maven Martha Stewart, about company prospects that led to claims of insider trading in violation of federal securities law. ${ }^{38}$

Investors may have been able to properly classify these unrelated events for a while. Enron and the other ongoing accounting scandals were about ways companies could dress up accounts to obscure the truth; the self-dealing loans made to executives at Adelphia and Tyco were relatively ordinary (if despicable) incidents of corporate misconduct that are the price paid

${ }^{35}$ See Marilyn Geewax, Accounting Reform Faces Key Vote in Senate Panel, Cox News Service (May 20, 2002).

36 Id. The SEC's efforts to create a new auditor oversight board pushed ahead and stood a strong chance of prevailing, though perhaps in a more watered-down version than what the Act actually produced. See infra.

37 These scams were about accounting in the same sense that Al Capone's were about tax evasion.

38 In the interest of full disclosure, I have personal and professional ties to the former ImcClone CEO and his family. 
for a market-based system of finance and governance; events at ImClone concerned arcane regulations governing the wrongful disclosure of nonpublic information. But non-experts in accounting, corporate governance, and securities law aren't good at maintaining these distinctions (especially when they've just lost enormous investment capital). The press showed little interest in doing so.

The gales of Enron were strong and these other episodes amplified them. The ultimate tipping point arrived in June 2002 with a true and pure accounting deception of such a large scale that there was no turning back from an Act of Congress, even for President Bush and his fellow free-market Republicans. ${ }^{39}$ That month WorldCom Inc.'s internal auditors revealed that top dogs had cooked its books to the tune of several billion dollars, a scandal with partners at other marquee names from the telecom boom, particularly Qwest Communications International Inc., whose part in the mischief was unrolled the next month.

Not coincidentally, several characteristics adorned each of the four massively scandalridden companies - Enron, Global Crossing, Qwest, and WorldCom. First, they were all new, with WorldCom effecting an initial public offering in $1995,{ }^{40}$ Global Crossing and Qwest both going public in 1997, and Enron revolutionizing during the mid-to-late 1990s from a stodgy natural gas company into a broadband and risk management mirage. ${ }^{41}$ Second, these four companies (the "Big Four") stand out as using the most appalling accounting and showing the most shocking corporate governance laxity, far different in daring, scope, and type from other accounting or corporate governance aggressions of the period (or any other). Third, all used as their outside auditor the once-venerable and now dead Arthur Andersen. While Enron's

\footnotetext{
${ }^{39}$ Two versions of a reform bill surfaced in committees. The tougher was proposed in the Senate by Sen. Paul Sarbanes, D-Md., Chair of the Senate Banking Committee; the weaker in the House by Financial Services Committee Chairman Michael Oxley, R-Ohio. (the accounting/auditing industry preferred Oxley's). As of May, whose would be prevail was up for grabs, if either of them would. See Marilyn Geewax, Accounting Reform Faces Key Vote in Senate Panel, Cox News Service (May 20, 2002).

40 WorldCom, Inc., a Georgia corporation, went public in 1995 through an offering by its controlling shareholder, Metromedia Company, though its business roots began in 1983 as LDDS Communications Inc. See WorldCom, Inc., Prospectus (filed with the SEC 1995).

${ }^{41}$ As of 1990, Enron was a Delaware corporation based in Houston that focused entirely on its historical business since 1930 of drilling for natural gas and providing pipelines to transport it; employed 7,000 people; held assets of $\$ 9$ billion; and generated revenue of $\$ 6$ billion. See Enron Corp., 1990 Annual Report on Form 10-K (filed with the SEC April 15, 1991). By 2000, the company had re-incorporated as an Oregon corporation, mainly to enable it to move into the electricity business by buying a utility in that state; ventured into the broadband and "risk management" businesses globally; employed about 21,000 people; and boasted of commanding $\$ 60$ billion in assets and of generating $\$ 100$ billion in revenue (both figures exaggerated; note the comparative revenue:asset ratios: $\$ 0.66$ revenue per dollar of assets in 1990 and $\$ 1.66$ revenue per dollar of assets in 2000!). In 2000, the only senior manager also a senior manager in 1990 was CEO Kenneth Lay, and all senior managers but one other had joined Enron during the 1990s. Compare Enron Corp., 2000 Annual Report on Form 10-K (filed with the SEC April 2, 2001).
} 
aggression was the manifest causal link to Arthur Andersen's demise, the interaction of all four with that erstwhile member of the Big Five auditing firms undoubtedly infected its culture. ${ }^{42}$

By mid-summer 2002 the wave of reports from each of the Big Four, and a few others, seemed endless. Worse, they were accompanied by parallel investigations into the practices, during the pre-March 2000 boom years, of additional culpable professionals. Besides auditors and executives, questions were raised concerning the role of securities analysts, lawyers and credit rating agencies. In many of these cases, particularly with securities analysts, damning evidence surfaced of their complicity or worse.

The multi-billion dollar scale of the Big Four scandals wrought proportional personal losses for millions of ordinary Americans. All this happened in the wake of the imploding financial bubble that stripped several trillion dollars from equity owners, a large percentage from the same ordinary Americans. This combination of forces produced a natural tendency to overreact. The upshot was the wholesale questioning of the quality of financial reporting throughout corporate America. These calls were made worldwide.

Some perspective was in order, but it rarely broke through. One would have classified the disparate scandals more clearly. This would have emphasized that Enron was essentially a Ponzi scheme, diabolically engineered and disguised by a few pathological fiends (President Bush was right about that); it would have emphasized that the other three members, as well as Adelphia, suffered from telecom mania on their way into the balloon, and telecom fever when it deflated. More broadly, everyone could have been reminded that when the balloon held helium, few complained about manifestly aggressive accounting when business performance was measured by revenue not cash, eyeballs hitting Internet sites not dollars customers paid. But victims do not like to be blamed.

Despite such perspectives - unpopular but plausible — cries to do something were loud and could not be ignored. The noise created political capacity in Congress for reform-minded legislators to craft improvements and put irresistible pressure on those more reluctant to regulate. The result was the Sarbanes-Oxley Act of 2002, the product of Congressional hearings conducted throughout the period following Enron's first sordid revelations and gaining momentum rapidly in the weeks before enactment in late July.

\section{B. The Big Four}

Mentioned by name in the Sarbanes-Oxley Act are two of the Big Four companies marking the apotheosis of abuses in auditing, accounting and corporate governance: Enron and Global Crossing. ${ }^{43}$ Their wretched stories warrant further summary to set the stage on which Sarbanes-Oxley was enacted, along with kindred companies WorldCom and Qwest (additional examples from other companies such as Adelphia and Tyco are included in the direct discussion of the Act in the following Part).

${ }^{42}$ So the Big Four accounting frauds redefined the US auditing industry from the Big Five to the Big Four.

43 Act, § 705. Designating companies or others by name is rare in a Congressional act, particularly one characterized as making "sweeping reforms." The Act's mention of Enron and Global Crossing underscores the more accurate view of the Act as patchwork and codification. It addresses particularized transgressions at named companies, and their cohorts, not systemic infirmities. 
1. Enron: Off-Balance Sheet Charades, Derivatives Duplicity, Ethics Erosion, Document Destruction (To Name A Few)

Enron through the 1980s was a natural gas drilling and pipeline company. It morphed through the financial boom of the late 1990s into a fiction trading nothing with itself to bank false revenues. Its CEO, Kenneth Lay, was idolized by fans of management strategies fashioned in the hallucinatory halcyon heyday of that period's financial fantasies. It appears more likely that he served as a fool while those around him beguiled the business and investment communities, and him. ${ }^{44}$

Revelations emerged in late 2001 of its failure over the preceding four years to make proper disclosure concerning various "related party transactions" and properly to account for "off balance sheet" transactions that ended up costing billions. These terms refer to a series of deals Enron made with several partnerships it created in which both Enron and top Enron executives held interests. The relationships were not disclosed and Enron's interest in the partnerships was so substantial that they should have been treated as consolidated entities on its books, rather than as minority investments.

Twenty percent of Enron's shareholders' equity was wiped out--a total of $\$ 2.2$ billion. The company restated its financials for the preceding four years, producing a twenty percent reduction to reported cumulative net income of nearly $\$ 600$ million (\$96 million in 1997, \$113 million in 1998, \$250 million in 1999 and \$132 million in 2000). On the balance sheet, consolidation increased debt by approximately $\$ 628$ million in 2000 and like amounts in earlier years. Bankruptcy followed shortly, along with numerous criminal and civil investigations and legal proceedings.

Enron exhibited many tricks from the accounting fraud cookbook, too numerous to catalogue here and well-chronicled many other places. ${ }^{45}$ Among highlights: it exploited asset securitization structures by pretending to sell assets that in fact it was pledging as security for loans, thus reducing its apparent debt:equity ratio while actually incurring debt levels with the opposite effect (failing an attempt to achieve proper off-balance sheet financing). Its managers assigned values to financial derivative products it peddled in its "risk management" business, using the most flattering assumptions, putting high asset values on exchanges and then listing those amounts on the balance sheet and listing theoretical gains in them as profits on the income statement. It permitted senior executives to participate in transactions with the company otherwise prohibited under the company's code of ethics. These were made possible by waivers of the code adopted by Enron's board of directors.

In the collapse, Enron's outside auditor, Arthur Andersen, engaged in a series of illicit efforts to destroy documents relating to its work with the imploding company. These actions, taken after it was known that investigations by the SEC and others were underway and that they included subpoena exercises, constituted obstruction of justice. The fallout in a jury trial in Texas was the collapse of the once-venerable accounting firm.

2. Global Crossing: Pro Forma Fantasies and Capacity Swap Dreams

Global Crossing Ltd. was founded in 1997 by someone with a checkered past who never ran a public company before. It described itself as providing telecommunications through an

44 See supra note $\mathrm{xx}$ (highlighting factual differences between Enron in 1990 and Enron in $2000)$.

45 E.g., Bankruptcy Examiner's Report; Power's Report; see also William W. Bratton, Enron and the Dark Side of Shareholder Value, Tulane L. Rev. (2002). 
integrated global network reaching 27 countries and hundreds of major cities around the world. One goal was to lay cables under the Atlantic and the Pacific Oceans that would connect all the continents in the world.

The company, incorporated in Bermuda, went public one year after its founding. It rapidly sported an insane market capitalization of nearly $\$ 40$ billion. Two years later it was bankrupt amid evidence of accounting fraud.

As with its cohorts in the telecom industry, Global Crossing never had a serious business plan, steady CEO, or cash flows. As with many companies lacking such pillars of corporate sustenance and afflicted by anemic fundamentals, it stepped up its acquisition activity. It tried to buy growth to jump start its stalled series of business plans. Thanks to its insane market capitalization, it had a highly inflated currency to use in paying for acquisitions, which giddy sellers accepted with glee.

Global Crossing was particularly adept at a form of financial felicity known as pro forma reporting, a technique used to conceal real GAAP results. One of the most devastating accounting practices to have emerged amid the tele-dot-com mania, the fiction of pro forma accounting presents results by making a variety of entries deliberately in violation of GAAP. The result is a picture of results that would have been achieved if GAAP rules were other than what they are.

The practice became so widespread during the 1990s that the difference between GAAP earnings per share and pro forma EPS widened throughout the decade. Some estimates indicate that the variance produced reported results twice as good as GAAP results. The number of companies indulging the habit grew, extending beyond the tele-dot-com circus that popularized it. More than half those in the S\&P 500 became hooked, though the tech industry took the cake.

This practice of ignoring rules managers don't like is not limited to arcane esoteric accounting mysteries. Many companies preferred to report results under the pro forma rubric by ignoring such items GAAP considers expenses as: sales commissions, marketing and personnel costs, and disbursements to start a new subsidiary. (No manager used the pro forma ruse to omit items of revenue such as sales, however.)

Global Crossing went to extremes, unmatched by more traditional companies and even those in its cohort, the leader in this charade among the Big Four. In August 2001, a finance executive discovered that the company and an Asian subsidiary had improperly reported pro forma values for cash revenue and adjusted cash flows based on measurements unrelated to usual accounting measures for cash receipts or earnings. He also expressed concern that cash amounts were inflated because they were based on transactions where either no cash was received or no monetary exchange occurred but rather only exchanges of capacity occurred.

The company dismissed the suggestions after determining that its auditor, Arthur Andersen, had signed off on its annual reports that reflected them and noting that in its public filings the way the company determined the pro forma numbers was fully disclosed, emphasizing that they should not be seen as an alternative to GAAP figures. In those filings, the company said it used those figures to assess the performance and liquidity of its business segments.

The company also took the position that it had disclosed that it bought significant assets from carriers who were also customers of the company, presenting the amounts of cash received 
by the company and included in cash revenue and adjusted cash flows, as well as the amounts of the cash commitments to those. ${ }^{46}$

Defending pro forma reporting by pointing to disclosure admonishing users to ignore it is the standard move. But it is patently disingenuous. If investors are to pay the pro forma figures no mind, then why is a company publishing them? It is the height of psychological manipulation. When earnings per share are reported on a pro forma basis at $\$ 3$ whereas GAAP EPS is $\$ 1.50$, you cannot tell a shareholder to ignore the $\$ 3$ and focus on the $\$ 1.50$. That is like trying to put toothpaste back in the tube.

After riding the false hopes the tele-dot-com roller coaster up to the peak, held up by crazy dreams reported in pro forma fantasies, on the way down the impulse to bolster results with financial trickery proved irresistible. The company looked to fellow industry looters for help, and found it everywhere it turned, including at Qwest, as discussed next.

As for the fallout at Global Crossing, the SEC launched an investigation. In February 2002, the company formed, at the request of the company's audit committee and Arthur Andersen, a special committee of independent directors, including members of its audit committee, to conduct a further review of the allegations. The special committee retained independent counsel and a firm of independent accountants other than Arthur Andersen to review the matter.

By April it had not yet sorted things out, announcing that it would delay filing its annual report for 2001 on the grounds that Arthur Andersen would not be able to deliver an audit report until the special committee completed its work. It had also filed for bankruptcy, and those proceedings complicated its ability to file with the SEC. It did, however, commit to making public the monthly reports of financial operations required to be filed with the bankruptcy court. In August, 2002, the bankruptcy court approved Global Crossing's agreement with its creditors to sell the company to an investor group under terms planning for it to emerge from the formal bankruptcy process by 2003.

3. Qwest: It Took Two to Capacity Swap ${ }^{47}$

Qwest Communications International Inc. was another newcomer to corporate America in the late 1990s. As with other telecoms, it suffered from excess investment in fiber optic cable and other resources. This put increasing pressure on its ability to generate sustained earnings and cash flows. For its part, Qwest teamed up with, among others, Global Crossing to create gimmick transactional accounting during the telecom boom.

Both were providers of local telephone services in the US. A leading trick was capacity swaps. The companies developed telecommunications capacity, incurring costs. Each then swapped that capacity with capacity of other telecom companies, including each other.

46 The indulgence of pro forma accounting to report rosier scenarios perverts an important exercise in accounting. It is sometimes important to create pro forma, as if, reports, to assess a variety of dynamic scenarios. SEC rules require doing so, for example, to show how two companies engaged in a business combination during a period would have affected presentation of their respective historical report if they had combined earlier. The perversion means that a blanket condemnation of pro forma reporting overreaches, but investors should avoid any company routinely reporting "as if" pictures of results they did not achieve except by ignoring the rules.

47 Not at Enron, which engaged in numerous kindred transactions with itself using divisions disguised as special purpose entities. 
The legitimate use of capacity swaps between rival telecoms was to enable the one to fill gaps in the other's networks. The faulty bookkeeping recorded revenue based on the value of the swapped capacity. The costs were capitalized, allocated over numerous future periods.

To simplify for illustration, the company might incur $\$ 100$ in costs to generate capacity a counterparty would agree was worth $\$ 120$ and get capacity worth $\$ 120$ in return. The $\$ 120$ is booked as revenue immediately, while the $\$ 100$ in costs is spread over 5 years at $\$ 20$ per year. Shazam.

The company got $\$ 120$ in revenue with $\$ 20$ in expense, for $\$ 100$ in gross profit on the deal. Conservative accounting would have treated the swap as merely that, booking no revenue and could well have treated the entire $\$ 100$ cost as an expense, contributing negative $\$ 100$ to the bottom line. The difference between $\$ 100$ to the good and $\$ 100$ to the bad is night and day.

Even using less conservative accounting, the $\$ 100$ might be capitalized, producing a first year annual charge of only $\$ 20$, but the difference between losing \$20 and making \$100 remains a difference between dusk and dawn.

But one pernicious characteristic of many accounting frauds is how easy it is to rationalize such moves. This occurs most readily concerning unprecedented transactions, such as capacity swaps, for which no direct authority exists. In their case, appeals to conventional accounting principles applied more broadly furnish some support. Elementary accounting principles direct that sales are realized on the income statement when effected and expenses reliably contributing to future revenue generation capitalized. Drawing on those simple principles enables an easy rationalization of their application to capacity swaps.

Determining how to account for novel transactions entails a dialogue between finance managers and their outside auditors. The conversation ordinarily sees the manager asking the auditor how the relevant industry is treating a transaction. The auditor usually appeals to such practice whether so prompted or not. The danger is that if the leading industry innovator is a fiend using aggressive accounting judgments, the consequent norm is fiendish. The result is a contagion of accounting aggression.

Capacity swaps were a case in point. They were an innovation of the tele-com cohort. The industry began to adopt the practice widely. The accounting developed uniformly, following the industry norms being ordained by the tele-com members of the Big Four. The result was awful accounting throughout the industry.

The precise accounting chosen emphasized revenue as a central measure of financial performance, an orientation the era's "investors" admired, widely shared, and awarded managers credit for bearing. The contagion spread to other areas of accounting where choices are permitted that have variable effects on revenue. Any time one alternative produced higher revenue compared to others, the tendency was to choose that one.

Another characteristic of all accounting aggressions is they cannot last. If you are realizing $\$ 100$ of revenue this year against capitalized expenses of $\$ 20$ to be taken annually over the next five, you are going to need something else in those succeeding four years to keep yourself in the same place. (It is the Red Queen in Lewis Carroll's "Alice Through the Looking Glass," who had to keep running just to stay in the same place.) This may be doable for a while, but it calls for doing more of the same thing. In the tele-com industry of the latter 1990s it meant doing more capacity swaps. But just as stamina constrains long-distance runners, new sources of phony accounting are finite.

Insiders tend to foresee doomsday earlier than outsiders, even the most sophisticated. This too occurred among the Big Four. When it did, an even darker side of direct managerial 
selfishness emerged. Numerous top executives at the Big Four (and elsewhere) sold shares at a profit during the deception, to the tune of several billion dollars, while their company was simultaneously selling new shares to the public for like-sized proceeds. ${ }^{48}$ As egregiously, other insiders sold shares amid post-bust periods of falling prices when federal pension law prohibited their company's pension fund from trading.

\section{WorldCom: Internal Control Overrides and Audit Failure}

WorldCom's fiasco typifies classic cases of fraudulent accounting accompanied by audit and internal control failure. As the nation's second largest long-distance telecommunications carrier (marketed under the MCI brand), WorldCom's business was in tatters by 2000 . The tech party wound down to its fateful fall. The telecom industry overspent, a downturn hit hard, and all players scrambled for business that wasn't there.

The company's habit of buying growth was thwarted when US regulators rejected WorldCom's bid to buy Sprint Corp. With no new revenue streams and expenses mounting, it turned to accounting massage. The first push, in late 2000, was steps to absorb expenses by writing down various reserves on the balance sheet. That saved $\$ 1.2$ billion in the last half of $2000{ }^{49}$ But more was needed. Line costs were next, with shifted amounts into asset accounts rising to the tune of $\$ 4$ billion in shorter order.

WorldCom's internal controls failed because they allowed senior financial executives to jigger ledger entries without immediate detection. On the other hand, they worked because a member of the company's internal audit team discovered the jig. The weakness relates to the time delay, from deception to detection. Worse, moreover, the internal audit that uncovered the scam was not a routine and scheduled check-up, but a special one called at the request of a newly-installed CEO.

The new CEO asked an internal auditor to spot check the capital expenditure records. One entry related to "line costs," disbursements made to local telecom networks to make phone calls and other connections. These would normally be characterized properly as routine business expenses, as the cost of generating current income. If so, such disbursements should have been recorded as current operating expenses, not as capitalized expenses, or assets to be written down over future periods.

And it wasn't just that the figures were listed in the asset accounts rather than the expense accounts. Apparently the journal entries, the original books, properly recorded the line costs as expenses; but during the account closing process, they were transferred to the asset accounts-and indeed sprinkled across these.

This is where internal controls should have intercepted the deception. Specific protocols in place should have ensured automatic posting of entries from the original journal into the financial statements during the closing process. Allowing managers to override those systems is an internal control failure.

The controller, in charge of the closing process, rationalized that these line charges would contribute reliably to future earnings, and there was some evidence that this belief was shared in the telecom community. But it did not jibe with GAAP. Several billion dollars of these

${ }^{48}$ E.g., Charles Gasparino, New York Sues Telecom Executives Over Stock Profits, Wall St. J. (Oct. 1, 2002) (state attorney general sued seeking $\$ 1.5$ billion in disgorgement from 5 senior telecom executives, including of WorldCom and Qwest).

${ }^{49}$ Indictment, Aug. 28, 2002 (reported in New York Times, August 29, 2002). 
disbursements were recorded in the cap-ex accounts, as assets on the balance sheet (not affecting the income statement), rather than in the expense accounts burdening net income.

As reported in 2001, line costs tallied about $\$ 15$ billion, but should have been recorded at $\$ 22$ billion. The result changed a year's worth of large losses into apparent paper profits for 2001 and 1Q 2002. Also of interest was the apparent fact that in prior years line costs were expensed; the change to cap-exing them in 2001 thus also required some explanation.

Following control procedures for an internal audit, internal auditors subsequently discovered these overrides and reported them to the company' audit committee chair, who was soon fired along with its CFO and controller. Wrath, ire, and wrenching ensued throughout the company, media, regulatory agencies, and Congress. Anguish reached all the way to the Oval Office where President George W. Bush condemned the bookkeeping stunt as "outrageous.",50

Treating operating expenses as capital expenditures is an age-old move and there is an age old tendency for the abuser to overdo it, festooning the balance sheet with a bright red flag. A cap ex account increasing by several billion dollars in a year stands out, even in a company WorldCom's size. After the controller made the overriding adjustments during the account closing process, additional internal controls should have raised a question about the size of these items, another case of internal control failure.

For internal controls to work, however, the company's senior management must want them to work. When the CFO and controller, along with the chairman of the board audit committee, wish to evade internal controls, it becomes far easier to do so. Internal controls must be designed to thwart collusion among senior management that could undermine them.

Defects in internal controls should be discovered during a company's external audit, and the external audit should discover override capabilities and related concealment. WorldCom's external audit, performed by erstwhile Big Five accounting firm Arthur Andersen, did neither. Andersen in February 2002 issued a report to the company's board audit committee pronouncing internal controls impenetrable regarding determinations of whether to expense or capitalize line costs. $^{51}$ Any such controls proved utterly porous.

Also at WorldCom, from 1998 through most of 2000, internal bookkeepers dutifully filed lists of deadbeat customers unlikely to pay their phone bills. Senior accounting officials routinely ignored these charge-off entries. Instead, they waited until the third quarter of 2000 and collected a large batch of receivables charge-offs together, aggregating \$405 million. When that lump sum charge to earnings was recorded, it was presented and treated as a nonrecurring event. The company played the game in reverse. In some periods the company over-estimated losses from charge-offs, creating the equivalent of a piggy bank that could be dipped into to boost reported results in periods of poor performance. ${ }^{52}$

50 See Simon Romero, Turmoil at WorldCom; WorldCom Facing Charges of Fraud; Inquiries Expand, N.Y. Times (June 27, 2002).

51 Arthur Andersen, Report to the Audit Committee of WorldCom, Year Ended December 31, 2001 (Feb. 6, 2002) (filed as an exhibit to WorldCom SEC filings made on July 8, 2002), reported in Kurt Eichenwald, Auditor Gave Assurances Of Safeguards Against Fraud, New York Times, July 9, 2002 (copy on file with the author).

52 These points are alleged in a shareholder lawsuit against the company, reported in Henry Senter, Inside the WorldCom Numbers Factory, Wall. St. J., August 21, 2002. 


\section{Regulators}

Corporate and accounting seas were not entirely calm before the collective realization in March 2000 of a financial bubble. And the Big Four were not the only accounting scandals of the era (every era has many). Numerous accounting transgressions were catalogued in the late 1990s, including at AOL-Time Warner, Rite Aid and Xerox as noted, plus scores of others (and, also as noted, exploitation of pro forma accounting was widespread). ${ }^{53}$ Regulators did not silently let them pass by. Instead significant regulations were imposed in the wake of a series of perceived accounting machinations tallied by the SEC in the latter 1990s, before the Big Four erupted.

Then SEC Chairman Arthur Levitt cited a series of fundamental and pervasive abuses in the field of financial reporting. ${ }^{54}$ These included some of the problems later uncovered at the Big Four, plus others: proper revenue recognition, appropriate creation and use of reserves and big bath restructuring charges. ${ }^{55}$ He proposed a broad-based range of cures for these ills, calling with characteristic melodrama for a "sweeping" change in American corporate culture.

The Levitt reforms included changes to the related accounting rules and toughening of SEC review. Levitt called on private standard setting organizations to join the cause, particularly the Financial Accounting Standards Board (FASB). He encouraged the Public Oversight Board to intensify its focus on audit committees and to recruit more members with financial experience and expertise (as opposed to legal, marketing, and public service backgrounds).

Levitt envisioned audit committees meeting more often and asking tougher questionswhat he called a "private sector response." He empanelled a blue ribbon commission to report on ways to enhance the audit committee role and ultimately called upon management itself and Wall Street to revitalize integrity in financial reporting by cooperating and supporting the foregoing initiatives. $^{56}$

The Levitt reform program emboldened the SEC to prosecute scores of enforcement actions against companies engaged in earnings management. The SEC adopted tougher rules governing audits, including a requirement that quarterly financial statements be reviewed by

53 Other examples include Cendant, McKesson, Sunbeam and Waste Management.

54 Arthur Levitt, The "Numbers Game," Remarks at the New York University Center for Law and Business (Sept. 28, 1998) <http://www.sec.gov/news/speeches/spch220.txt>; Arthur Levitt, A Partnership for the Public Trust, Remarks Before the American Institute of Certified Public Accountants (AICPA) (Dec. 8, 1998) <http://www.sec.gov/news/speeches/spch230.txt>; Lynn E. Turner, Current Projects of the Office of the Chief Accountant, Remarks at the Colorado State Society of Certified Public Accountants 1998 SEC Conference (Dec. 3, 1998) $<$ http://www.sec.gov/news/speeches/spch243.htm>.

55 Non-Big Four member Tyco International Ltd., a Bermuda corporation, also routinely sanitized the accounting of acquisition targets before closing to boost financial appearances after closing.

${ }^{56}$ Ira M. Millstein, Introduction to the Report and Recommendations of the Blue Ribbon Committee on Improving the Effectiveness of Corporate Audit Committees, 54 Bus. Law. 1057 (1999). 
auditors and a broad regulation that substantially curtailed the kinds of non-audit services auditors could perform for clients without impairing their independence. ${ }^{57}$

The Levitt reforms required board audit committees to review and vouch for the accuracy of financial statements, disclose whether they signed off on the financial statements, state whether a written charter spells out the committee's duties, and submit any charter to the SEC every three years. The stock exchanges adopted rules requiring listed companies to disclose whether members of the audit committee are independent of management and requiring audit committee members to have financial backgrounds.

The legal landscape changed in a few other potentially relevant ways in the latter 1990s. First, in 1995 Congress passed the PLSRA (overriding a Clinton veto). Its purpose was to deter frivolous securities fraud lawsuits, using a series of devices such as heightening pleading standards. In 1998, the restrictions were tightened to prevent the plaintiffs' bar from filing similar suits in state court. The combination may have overshot the mark, deterring meritorious securities fraud lawsuits as well.

Second, the Supreme Court, in a major securities fraud case-Central Bank of Denverheld that the federal securities laws impose liability on primary perpetrators of securities fraud. According to the Court's interpretation of the statutes, they do not create liability in secondary actors, such as accountants, auditors, and attorneys. There is obviously some risk of increased laxity among such gatekeepers when they know their own liability is not at stake when fraud is afoot. $^{58}$

Third, in 1999 Congress substantially repealed the Banking Act of 1933 (commonly called the Glass-Steagall Act), including its strict separation of the commercial and investment banking industries. From 1933 through 1999, some banks collected deposits and made loans and provided other services for corporate customers (commercial banks). Others underwrote securities in public offerings (investment banks). Investment banks were intended to serve a public gatekeeping function, helping to assure that public offerings were vetted, with risks and financial realities fully disclosed. When the same firm could do both-have commercial business relationships with a customer and sell its securities to the public-risks of conflicts rose.

Unanswerable questions arise concerning whether the Big Four were caused, enabled or promoted by any of these changes in the legal landscape, as well as the role the Levitt reforms may have played in uncovering them. Throughout the period these changes were made, however, and since the securities laws were first enacted, the SEC has sought broader powers to rein in excesses. It needs Congressional cooperation to cement that power. Neither Levitt, nor any other SEC Chairman, can do it alone.

As administrations and commissioners come and go, the SEC is permanently engaged in a regulatory mission invariably confronting resistance. Those it oversees, from auditors to issuers to professionals, work to comply but some also use strategies either to avoid or evade. Catching these strategies often calls for powers the SEC lacks. It responds with appeals to Congress for power enhancement, while the regulated lobby against it. For the SEC to win the cat and mouse game through enhanced power, political winds must favor it. The Big Four

57 These were codified as part of the SEC's Regulation S-X, which are in turn codified as federal law by the Sarbanes-Oxley Act, as discussed below.

58 See John C. Coffee, Understanding Enron: It's About the Gatekeepers, Stupid, 57 Bus. Law. 1500 (2002). 
created those winds, putting Congress in its corner. In fact, the SEC has long sought to federalize of the provisions that the Act federalizes. ${ }^{59}$

Responding to SEC desires, and public pressure, the Congress and President added their say in the summer of 2002. Facing crisis, politicians (as well as others) need to feel in control. For legislators, regulators and prosecutors, this means responding to crisis with legislation, regulation, and prosecutions. ${ }^{60}$ The result of this need following the Big Four was legislation enthusiastically embraced by the likes of President George W. Bush, a previously outspoken opponent of the precise form the final legislation took. But it was legislation he could understandably accept for its essential character is codification, political rhetorical flourishes of its "sweeping reform" echoed widely notwithstanding.

\section{The Act}

The Sarbanes-Oxley Act of 2002 modifies governance, reporting and disclosure rules for public companies, bolsters criminal and civil liability for securities fraud, founds a new oversight board for independent audit firms to be paid for by stockholders of public companies, embraces restrictions on audit firms engaging in various non-audit services for their clients, requires internal control certifications by CEOs and CFOs and prohibits corporate loans to directors. $^{61}$ "Sweeping" as this sounds in its breadth, all changes made by the Act had been discussed among corporate governance and accounting devotees for years. Virtually all were already in effect as a matter of custom or practice and/or due to requirements imposed by stock exchanges, regulators, state law, or other provisions of federal law, as we will now see. In this view, the changes may be "sweeping" or "far-reaching," but they are hardly "reforms."

The changes are more likely to have psychological rather than substantive effects. The most immediate example of this effect of the Act-perhaps one of its goals - concerned the Act's requirement that CEOs and CFOs certify financial statements as "true and fair." Existing law since the $1930 \mathrm{~s}$ has carried substantially that requirement, and indeed extends it to all directors on the board. ${ }^{62}$ A charitable view of this piece of the legislation is that it is intended to heighten executive attention to the stakes. While adding little new, it did create news-news that investors could consider "good news" when that commodity was scarce. ${ }^{63}$

59 See Karmel, supra.

60 And law professors write articles in response.

61 Detailed analysis of these provisions appears below.

62 The Act's new certification is in addition to and leaves unchanged pre-existing signature requirements for quarterly and annual reports filed under the Exchange Act. Exchange Act Rule 12b-11(d); 17 C.F.R. 240.12b-11(d). Since those certifications are part of the report, moreover, those signatures also certify those certifications! (I'm not kidding: this is precisely what an SEC implementing rules says. Securities and Exchange Commission, Certification of Disclosure in Companies' Quarterly and Annual Reports, Release Nos. 33-8124, 34-46427, IC-25722; File No. S7-21-02, 67 Fed. Reg. 57276 (2002)).

63 The requirements and accompanying news also reportedly confused some executives. Confusion arose in part from the Act's two different certification sections (302 and 906). They require different attestations and went into effect at different times (as discussed below). Contributing to the confusion, the SEC earlier mandated yet a different attestation effective at yet a different time. Securities and Exchange Commission, Release No. 34-46709 (June 14, 2002), 67 Fed. Reg. 41877 (subsequently withdrawn in light of the Act). One consequence of the reported confusion was more media and public attention to the various requirements, increasing 
This view of the certification is supported by those having the least interest in the "sweeping" mantra party line. As a senior UK executive commented in connection with concern that the rules would extend to UK companies that happen to have a secondary stock market listing in the US, the new law amounts merely to "an extra hassle." 64 At the cynical extreme, what the Congress and President did in creating this law was exactly the crime for which executives must pay: fooling investors. ${ }^{65}$

The following discussion classifies various provisions of the Act as codification or patchwork, noting a few areas of actual innovation, and concluding by presenting the areas of real potential innovation, the studies mandated. Topically, discussion moves from auditing and corporate governance (the Act's two center stages), then on to enforcement and other matters.

\section{A. Auditing Standards and Supervision}

For generations, establishing generally accepted auditing standards (GAAS) had been the province of the American Institute of Certified Public Accountants (AICPA). It has used various arms and structures to exercise this authority, often reconfiguring structures following periodic audit failures that produced public calls and SEC pressure for reform. Of late, the AICPA's Auditing Standards Board led the effort, supervised by the AICPA's SEC Practice Section's independent Public Oversight Board (POB) and, ultimately, the SEC. The AICPA is a professional organization comprised of CPAs and serves as a trade group for the profession. The POB was funded by the AICPA, a mix that risked sacrificing its independence and objectivity in promulgating GAAS and supervising the public auditing industry.

The Act changes this structure. It creates the Public Company Accounting Oversight Board (the PCAOB). ${ }^{66}$ A self-regulatory organization, ${ }^{67}$ the SEC appoints and oversees its five-member board. Monitoring duties include reviewing audit procedures and policies, registering public accounting firms, maintaining standards concerning audit reports, and the conduct of oversight, disciplining and sanctioning of public accounting firms. ${ }^{68}$

Several major structural differences stand out. First, the PCAOB is a creature of statute, not grace. Second, a majority of its five members will be non-CPAs and its chair cannot have practiced public accounting during the year before becoming chair. Third, it will be funded by public company shareholders, not the AICPA. Fourth, members will be full-time and serve 5year terms (with a two-term limit) and be subject to removal for cause by the SEC.

These moves are intended to strengthen the PCAOB's independence from the profession, a longstanding philosophical and practical conflict between the SEC and the AICPA. Whether they will work is uncertain. But this is a major step, perhaps the silver bullet of the Act.

their perceived significance. Whether so intended or mere happenstance, the process began achieving its objective more quickly than a single clear directive would have done.

64 Matthew Jones, et al., Alarm Eased over US Fraud Law, Financial Times, August 12, 2002.

65 See David J. Sorin, Kristina K. Pappa \& Emilio Ragosa, Sarbanes-Oxley Act: Politics or Reform? Statute's Effects Are Not as Profound as Legislators Would Have Us Believe, N.J.L.J. (Sept. 2, 2002) (Act "may foster future investor confidence" but to securities professionals it "merely gives the illusion of increased accountability").

66 Act, $\S 101$.

67 Act, $§ 107$.

${ }^{68}$ Funds generated from fines will go to support a scholarship for students pursuing accounting degrees (not to the US Treasury as previously). 
Silver bullets are tricky things. When they strike their targets they are deadly; but when they miss, meaningless or worse. ${ }^{69}$ Whether this body achieves anything useful will depend virtually entirely on whom is appointed. ${ }^{70}$ Judging by the work of comparable bodies attempting to oversee the accounting and auditing professions in past decades, this will not be an easy job to do well. Enormous lobbying pressure from those industries can be expected to dampen any major initiatives.

With the Congress having just expended substantial legislative firepower on the subject, there is meaningful risk that the PCAOB will lack Congressional support for significant initiatives it may pursue. On the other hand, the nine studies the Act directs to be undertaken suggest Congress remains ready to respond with additional legislation if warranted. At least in the start-up phase, this can give the PCAOB some momentum.

From another point of view, the perception of greater independence may be more structure than substance. Auditors in practice, and the AICPA and Auditing Standards Board in standard setting, always operated under threat of SEC rebuke. Client advice was invariably couched in terms of whether a position would pass muster at the SEC. That threat remains the key disciplining power that will apply to the PCAOB. To that extent, less has changed than meets the eye.

It is a common move, amid regulatory failure, to replace one regulatory body with another. Congress did it in response to the accounting and regulatory debacle exposed amid the implosion of the savings and loan industry. ${ }^{71}$ The SEC has done it repeatedly with those who set auditing and accounting standards.

After the SEC's formation in $1934,{ }^{72}$ it led the promulgation of accounting and auditing standards, issuing Accounting Series Release No. 1 in 1937. In 1938, the SEC issued Accounting Series Release No. 4, indicating that financial statements must be prepared in

${ }^{69}$ The term magic bullet was reportedly first used in the quest to cure syphilis by the German immunologist, Paul Ehrlich, co-Nobel Prize winner in 1908, to mean an ideal therapeutic agent that kills unhealthy tissue without killing healthy tissue. Silver bullet is a derivative, designating a talisman to ward off werewolves and vampires. Both phrases now denote a cure offered as having no side effects, but in fact carrying meaningful risks of unintended adverse consequences. See William Safire, On Language; Drug-War Lingo, N.Y. Times (Sept. 24, 1989).

70 Board member identity is the central issue concerning any board, whether corporate, regulatory, oversight, or otherwise. Fierce battles rage on the issue, and the early days of the PCAOB were no exception. SEC Chairman Pitt first proposed and then recanted on naming as PCAOB chair John Biggs, head of TIAA-CREF and long an outspoken critic of the public auditing profession. See Stephen Labaton, S.E.C. Chief Hedges on Accounting Regulator, N.Y. Times (Oct. 4, 2002). The more things change ...

71 The Federal Savings and Loan Insurance Corporation (FSLIC), industry regulator, failed to (a) prevent industry collapse by lax oversight that enabled S\&Ls to invest insured deposits in highly-risky securities and (b) provide adequate resources to reimburse resulting losses. The Congressional upshot was to shut down the FSLIC (and its kindred regulator the Bank Board) and substitute the Resolution Trust Corporation and the Office of Thrift Supervision. See Financial Institutions Reform, Recovery and Enforcement Act of 1989 (FIRREA), 102 Pub. L. No. 242, §§ 401, 501, 103 Stat. 183, 354, 364-394.

72 The Securities Act, passed in 1933, put the Federal Trade Commission in charge of receiving filings under it in the early days of the regime. 
accordance with accounting principles having substantial authoritative support. That invited, the next year, the profession to establish the Committee on Accounting Procedures (CAP) to provide authority. Criticism of CAP's inability to establish uniformity led, in the 1950s, to the creation of the Accounting Principles Board (APB). As usual, criticism eventually led to its demise, giving rise in 1973 to the Financial Accounting Standards Board (FASB). ${ }^{73}$ The FASB drew immediate criticism and still does, making its survival its most important achievement. ${ }^{74}$

As for auditing standards, though the AICPA managed to remain at the standard-setting helm from 1939-2002, it used varying command and oversight structures that changed in response to pressure for reform about once a decade. Though precise causes of oversight board substitution or overlay vary, any amateur logician can infer from change the signal that results had been unsatisfactory. And so it goes, with the PCAOB. Substitution may be desirable, important, even essential, but its power to reform remains for action to tell.

\section{B. Audit Practice and Process}

Audits are a central feature of US financial reporting, constituting a hinge on which capital is allocated and attracted using securities markets as the vehicle. Outside auditors examine internal controls and financial statements, applying a variety of tests and conducting selected reviews of management personnel, processes, and systems. Throughout, the auditor has long interfaced with the board of directors and, in the last two decades, with the board audit committee. The Act addresses aspects of this attestation function in a few patchwork modes, with a heavy view to the scandals to which Congress was responding and with substantial codification of extant practices. ${ }^{75}$

\section{Audit Committees}

The SEC must adopt rules requiring stock exchanges to prohibit listing securities of companies not complying with the following audit committee rules. ${ }^{76}$ First, the committee must be directly responsible for appointing, paying, and supervising outside auditors. Second, all committee members must be independent and not collecting fees from the registrant (by consulting or otherwise). Third, committees must establish procedures to promote employee reporting of misconduct and protect reporting employees (whistle-blowers). Fourth, committees

${ }^{73}$ David Ruder, Remarks at the $16^{\text {th }}$ Annual AICPA National Conference on SEC Developments (Jan. 10, 1989) (then SEC Commissioner Ruder on the death of the APB and birth of FASB: "as has been the case throughout with the standard setting process, criticism arose again").

74 So said FASB Chairman Edmund L. Jenkins upon the FASB's $25^{\text {th }}$ anniversary, celebrated by a conference at New York University.

75 For a broad and detailed account of numerous auditing standards provoked by periodic episodes of public disgust with financial reporting, including instances of interaction between the SEC and the profession that produces them, in the context of debates of the late 1980s concerning the auditor's responsibility for detecting fraud, see Joseph I. Goldstein \& Catherine Dixon, New Teeth for the Public's Watchdog: The Expanded Role of the Independent Accountant in Detecting, Preventing, and Reporting Financial Fraud, 44 Bus. Law. 439 (1989).

76 Act, $\S 301$. The Act does not require boards of directors to form audit committees. It does provide that absent committee formation, the entire board is deemed to constitute an audit committee. Given the Act's particular constraints on audit committee composition and obligation, most boards lacking one will establish a committee. (For listed companies, again, exchange rules require audit committees and most companies already have one as a matter of practice. E.g., N.Y. Stock Exchange, Listed Company Manual, 303.01(A)). 
must be empowered to retain independent counsel and other advisors. Fifth, the company must provide sufficient funding, as the committee determines, to pay outside auditors and committee advisors.

None of this is new, though the rules formalize, federalize, and incrementally extend requirements. Stock exchange rules approved by the SEC in 1977 and in effect since require audit committee responsibility and independence. ${ }^{77}$ A chief function of audit committees has always been internal control promulgation that included whistle-blower protections. Audit committees, as a matter of state law, are always entitled to hire outside advisors, and invariably do so, and to compensate them and auditors. ${ }^{78}$

The Levitt audit committee reforms that went into effect in the late 1990s and the stock exchange rules mandating audit committee independence brought actual change to the quality and practice of audit committees. ${ }^{79}$ These provisions of the Act ride the wave those reforms brought. $^{80}$

\section{Financial Expert}

The SEC must adopt rules requiring quarterly and annual disclosure of whether at least one audit committee member is a "financial expert" and, if not, why not. ${ }^{81}$ The SEC is directed to

77 E.g., N.Y. Stock Exchange, Listed Company Manual, 303.01(B)(2)(a) ("Each audit committee shall consist of at least three directors, all of whom have no relationship to the company that may interfere with the exercise of their independence from management and the company"). Additional independence rules are applied with respect to employees, business relationships, cross-compensation committee links (no director can be on the audit committee if they also serve on another company's board and another company executive is on that board's compensation committee) and immediate family. Id. 303.01(B)(3). See New York Stock Exchange, Inc., Exchange Act Release No. 13,346, 1977 SEC LEXIS 2252 (Mar. 9, 1977); see also Noyes E. Leech \& Robert H. Mundheim, The Outside Director of the Publicly Held Corporation, 31 Bus. Law. 1799 (1976).

E.g., Del. Gen. Corp. L. $\$ 141(\mathrm{c})(2)$. The Act's express authorization of committee engagement of independent advisors raises potentially complex questions concerning how the professional defines the client's identity. In the case of lawyers, except in peculiar situations accompanied by express specifications, the corporation is the client, not the committee. See Simon Lorne, Sarbanes-Oxley: The Pernicious Beginnings of Usurpation?, Wall St. L. (Sept. 2002) (the Act thus carries "the embryonic suggestion of the committee as a separately cognizable 'person.' Where that suggestion will lead, only time will tell, but it is surely an important concept.").

${ }^{79}$ New York Stock Exchange rules require audit committees to prepare and publish a charter spelling out its purpose and duties, including retaining and firing auditors, reviewing audit reports on internal controls, discussing financial statements with management and outside auditors, discussing earnings press release, and a host of other matters, including those mentioned in the Act and many others beyond. N.Y. Stock Exchange, Listed Company Manual.

${ }^{80}$ See David J. Sorin, Kristina K. Pappa \& Emilio Ragosa, Sarbanes-Oxley Act: Politics or Reform? Statute's Effects Are Not as Profound as Legislators Would Have Us Believe, N.J.L.J. (Sept. 2, 2002) ("the 'new' mandates related to the role of audit committees impose very few additional duties. Rather, the act merely sets forth what many in the securities bar have long deemed to be best practices.").

81 Act, § 407, amending 15 U.S.C. 7265. 
define the term financial expert, considering a person's education and experience and probable knowledge of GAAP, financial statements, audit committee functions, internal accounting controls and preparing or auditing financial statements.

This is another dose of weak tea. It requires nothing substantive. In fact, the Act does not go as far as stock exchange rules on the subject. These affirmatively require that all audit committee members possess some financial expertise and that at least one have direct experience in financial reporting. ${ }^{82}$ The provision goes little further than the proselytizing posture of the Levitt reforms that called for greater financial expertise on audit committees. The added disclosure requirement may be useful in promoting competence on audit committees, but the approach is modest.

From another point of view, there is something innovative in the approach. It resembles the European best practices approach to corporate governance and related controls. The European model often is based on an articulated set of best practices, usually promulgated by private standard setters. Lawmakers, or those standard setters, call for companies to comply with suggestions on a voluntary basis, but also require them to disclose and explain deviations from best practice. $^{83}$

Apart from that modest structural innovation, however, the have-or-disclose provision doesn't amount to much. An audit committee's central function is financial. It is not possible for a member to contribute meaningfully without a measure of financial expertise. A financially illiterate member is as apt to subtract rather than add value. It is like asking a layperson to serve on a committee to assess the efficacy of a new drug to cure cancer. In this area where a mandate seems easily justified, Congress opted for timidity.

\section{Auditors}

Outside auditors must report to audit committees a series of things under the Act, all of which had been functionally required apart from the Act but now constitute formal federal law. First, auditors must report to the committee all critical accounting policies and practices. ${ }^{84}$ As examples, for merchandising companies making substantial credit sales this would include accounts receivable aging and reserve practices, while for oil companies it would include assessment of proven and probable reserves. It should include broader policy areas as well, such as stock option accounting and periodic impairment assessments for fixed assets including goodwill. This is the standard practice.

Second, auditors must report to the audit committee all alternative GAAP treatments of financial information they discussed with management, the implication of the choices, and which the auditor prefers. ${ }^{85}$ This report would capture basic provisions such as depreciation methods on fixed assets and measuring the costs of goods sold for inventory purposes. It would extend to areas such as the expensing or capitalization of various disbursements and the timing of revenue recognition-precisely the sort of mischief practiced among the Big Four and others and precisely the sort of thing auditors of integrity would discuss with audit committees of integrity.

\footnotetext{
${ }^{82}$ E.g., N.Y. Stock Exchange, Listed Company Manual, 303.01(B)(2)(b)-(c) ("Each member of the audit committee shall be financially literate." \& "At least one member of the audit committee must have accounting or related financial management expertise.").

83 See ABA, Section on Business Law, 57 Bus. Law. (2002).

84 Act, $\S 204$.

85 Id.
} 
Third, auditors must share with audit committees all material written communications between the auditor and management, including management letters and schedules of unadjusted differences of opinion. ${ }^{86}$ These letters and schedules relate to the sensitive discoveries and questions audits raise. They may include weaknesses in internal control systems the auditor discovered in the case of management letters or disagreements about which of two alternative approaches to reporting a matter to take in the case of schedules. All these practices are undertaken by auditors in the ordinary course. ${ }^{87}$ On this score, again, the Act federalizes common sense and general practice.

Auditor independence is beefed up, at least nominally. The debate centers on where to draw the bright lines to prevent compromising objectivity, real or apparent. The Act starts with two bright lines.

First, no audit firm is independent if certain company executive, financial or accounting officers worked there and on that company's audit within the year before the start of the audit service in question. ${ }^{88}$ This quite modest thought is one recently endorsed by the Independence Standards Board, the now-defunct joint venture of the SEC and the AICPA created during Chairman Levitt's tenure to establish independence standards for auditors. ${ }^{89}$

Second, attacking a clear independence threat, the Act provides that officers and directors or their agents are forbidden to fraudulently influence, coerce, manipulate or mislead any accountant auditing the company's financial statements. ${ }^{90}$ It would shock most people if it were the case that, but for the Act, a public company manager could fraudulently influence the company's auditor without running afoul of the federal securities laws. But as far as adding a pair of suspenders to a belted trouser goes, this is as correct a place as any.

On the other hand, the section vests civil enforcement authority exclusively in the SEC. Not to cut off existing duties and rights of action, however, the section then announces that the provision does not preempt pre-Act law. The provision, in other words, makes no change in the duties of management or the rights of shareholders. Its sole effect is to expressly authorize an SEC enforcement action for violations, power the SEC apparently thought was in doubt. ${ }^{91}$

To enhance the independence of individual auditors as opposed to audit firms, auditors must rotate lead and reviewing partners so that neither role is performed by the same accountant for the same company for more than five consecutive years. ${ }^{92}$ As with many other Act provisions, this has clear reference to Enron and WorldCom, both of which were audited by Arthur Andersen through small local Andersen offices where the lead partner may have developed a client relationship so close that his independence was impaired. Nice going, but this

${ }_{87}^{86} I d$.

${ }^{87}$ See Communication of Internal Control Structure Related Matters Noted in an Audit, Statement on Auditing Standards No. 60 (Am. Inst. of Certified Pub. Accountants 1988); see generally Report: "Management" Reports on Internal Control: A Legal Perspective, 49 Bus. Law. 889 (1994) (by the Ad Hoc Working Group of the Committee on Law and Accounting, Section of Business Law, of the American Bar Association).

${ }^{88}$ Act, $\S 206$.

89 The Independence Standards Board operated from 1999-2002. I served as Director of its Task Force on Alternative Practice Structures of Audit Firms during much of that time.

${ }^{90}$ Act, $\S 303$.

${ }^{91}$ SEC enforcement powers are discussed further below.

${ }^{92}$ Act, $\S 203$. 
is another instance of federalizing as law existing auditing standards (though existing auditing standards set the limit at seven years which the Act cuts five). ${ }^{93}$

Stronger medicine was considered. One possibility is to require mandatory rotation of firms. A virtue of this approach is it would probably encourage more conservative accounting when choices are possible. The first thing new auditors tend to do is hunt for aggressive accounting and pressure to reverse it. The looming threat of such second guessing would ordinarily induce incumbent auditors to insist on the more conservative approach at the outset. Costs of the mandated firm rotation are the start up burdens of firms learning peculiar systems and protocols. ${ }^{94}$

Internal controls are a main focus of the Act, both as to managerial responsibility and audit attestation. As to auditors, the PCAOB is required to establish rules specifying the content of the traditional auditor's letter be expanded to include a description of "the scope of the auditor's testing of [a registrant's] internal control structure and procedure." ${ }^{\circ 5}$ The letter must also present the findings from that testing and an evaluation of whether controls produce record retention and reporting compliance necessary to produce GAAP financials and meet managerial and board directives. The practice has long been standard; what's new is a required paragraph in the standard audit letter. ${ }^{96}$

\section{Non-Audit Services}

Auditor independence is strongly influenced by what role auditors assume for their clients in addition to certifying financial statements. Roles mushroomed in the past few decades as firms became multi-national, multi-service conglomerates. Relationships that developed included pension management; investment advisory; broker/dealer; personal trust services for the client or its officers, directors and significant shareholders; bookkeeping; record-keeping; payroll; and executive recruiting.

Curtailing the influence of these activities, the Levitt reforms defined a range of services auditors could not render and still remain independent. Amid the pressure enabling and resulting from Levitt's efforts, most firms had withdrawn from those businesses, by selling them to others (as Ernst \& Young did to Cap Gemini) or spinning them off in IPOs (as KMPG did). ${ }^{97}$

Though these steps rendered the point substantially moot, the Act restricts them, much as an errant cowboy locks the stable after his wild horses have escaped. ${ }^{98}$ Strikingly, the Act restates and restricts exactly the same services restricted by the Levitt reforms, using almost exactly the same language. ${ }^{99}$ Under the Act (as under the Levitt reforms), auditors in no event

${ }^{93}$ See AICPA Division for CPA Firms, SEC Practice Section, SECPS Manual 1-6, 2-24.

94 The Act requires the Comptroller to study the mandatory audit firm rotation possibility. Act $\S$ 207 (discussed infra).

95 Act, $\S$ 103(a)(2)(A)(iii). Those are in turn required by the Act. Act, $\S$ 404(b) (discussed infra).

96 See Report: "Management" Reports on Internal Control: A Legal Perspective, 49 Bus. Law. 889 (1994) (detailed history of internal controls by the Ad Hoc Working Group of the Committee on Law and Accounting, Section of Business Law, of the American Bar Association).

${ }^{97}$ KMPG Consulting subsequently changed its name to "Bearing Point."

98 The Act rightly reflects a prophylactic dimension in functionally ignoring the voluntary (though coerced) withdrawal of audit firms from consulting businesses.

99 Compare Act $\S 201$ (amending 15 U.S.C. § 78j-1) with S.E.C. Reg. S-X, 17 C.F.R. § 210.201(c) (4)(i)-(ix). 
may perform any of the following services for audit clients: bookkeeping; financial information systems; appraisal, valuation or fairness opinions; actuarial; internal audit; human resources; broker/dealer, investment adviser, or investment banking services; or legal and expert services. Expressly permitted are comfort letters relating to securities underwriting.

One seemingly modest but potentially significant difference between the Act and the previously-adopted Levitt reforms concerns the duration of the ban on non-audit services. The Act forbids listed non-audit services "contemporaneously with the audit," while the Levitt reforms prohibited them "at any point during the audit and professional engagement."100 The concept of "professional engagement" enlarges restricted periods to include time before the audit (from engagement) to time after formal completion. As an enforcement matter, the broader rules would seem to control the narrower Act, rendering the section a dead letter. ${ }^{101}$

Finally, audit committees must pre-approve all services, including comfort letters, performed by outside auditors and disclose them in regular periodic reports. The committee can delegate this authority to members who are independent directors. As a practical matter, again, audit committees had this duty beforehand. The rules are sensible and defensible. The main difference is now they're required by federal law.

\section{Corporate Governance}

Ordinarily the province of state law, corporate governance has grown in the last two decades to encompass a variety of instruments of federal securities regulation touching on the performance standards and certification functions of senior mangers. The Act follows suit, though makes some express federal incursion into territory once governed by states.

\section{CEOs and CFOs}

CEOs and CFOs must certify periodic reports. For the drop-dead early certifications due the first time around, August 2002 for most, officers had to certify that reports containing financial statements "fully comply" with Section 13(a) or 15(d) of the Exchange Act and that reports "fairly present, in all material respects, the financial condition and results of operations of the company." 102

This preliminary certification requirement captivated news analysts, investors, and corporate watchers during Summer 2002. In fact, however, it is a yawn. This sort of certification requirement-that the statements comply with regulations and fairly present resultshas always been a requirement of the federal securities laws. Those singled out to make the certifications, CEOs and CFOs, are invariably named as defendants in private securities lawsuits and SEC enforcement actions. ${ }^{103}$ As a practical matter, the chief effect is those officers will now insist that subordinates certify what they send up-generating "sub-certifications." 104 The most

\footnotetext{
${ }^{100}$ Reg. S-X, 17 C.F.R. § 210.2-01(f)(5) (defining “audit and professional engagement period”).

101 On the other hand, the regulations contained a number of qualifications to the scope of services limitation, loopholes the Act seals. The Big Four gave Congress political will to defeat auditing lobbyists that pre-Enron Chairman Levitt lacked.

102 Act, $\S 906$. Knowing or willful violation results in criminal penalties, including fines of up to $\$ 5$ million and prison up to 20 years. These and other penalties are discussed infra.

103 See David J. Sorin, Kristina K. Pappa \& Emilio Ragosa, Sarbanes-Oxley Act: Politics or Reform? Statute's Effects Are Not as Profound as Legislators Would Have Us Believe, N.J.L.J. (Sept. 2, 2002).

104 See Martin Lipton \& Laura A. McIntosh, Corporate Governance in Light of Sarbanes-Oxley and the NYSE Rules, M\&A Lawyer (Sept. 2002), at 8.
} 
this provision did was shine attention on the subject, not an incidental effect but far more modest than was widely believed.

Future certifications go beyond these basics, giving this provision of the Act the sharpest teeth in the legislation (though exactly how sharp are these teeth remains to be seen). Future quarterly and annual reports require the additional certification that the CEO and CFO designed corporate internal controls to ensure the information flows the officer's way and that the officer evaluated their effectiveness within the preceding 90 days. ${ }^{105}$ These officers also must affirm that they disclosed discovered control deficiencies or weaknesses to their outside auditors and board audit committee, as well as any fraud, material or not, involving employees with significant internal control roles. ${ }^{106}$

These provisions look to prevent CEOs and CFOs from hiding behind the defense of ignorance. The clear line of provenance points to the Enron scandal amid which several senior executives testified before Congress that they lacked knowledge of underling financial fraud, contending that they couldn't possibly be aware of all activities, including fraudulent practices, within the massive company. ${ }^{107}$ The rules may be sensible, but few knowledgeable people really believed those people and none but the most sympathetic or gullible absolved them from responsibility.

Keeping the heat on the $\mathrm{CEO}$ and $\mathrm{CFO}$ are penalty rules that impose forfeiture of bonuses if their company must restate its financials due to misconduct producing material noncompliance with financial reporting requirements. ${ }^{108}$ Those officers will have to pay back bonuses and stock options received for the year after the incorrect report was made, along with any profits generated on the award during that year. This is a novel and proportionate penal scheme, intended to destroy what many saw as one part of the incentives for manipulation in the first place, and also to discourage poor accounting judgments that are the product of mere haste, bad judgment, or other carelessness. ${ }^{109}$

\section{Internal Controls and Codes of Ethics}

The SEC must promulgate rules requiring annual reports to contain an internal control report expressing management's responsibility for establishing and maintaining adequate internal controls for financial reporting and assessing their effectiveness. ${ }^{110}$ This mandate broadly restates legal requirements imposed by Congress in the 1977 Foreign Corrupt Practices Act, the

${ }_{105}^{105}$ Act, $\S 302$.

106 One strange provision of the Act expresses the "Sense of the Senate" that CEOs should also sign a company's federal income tax returns. Act, $\S 1001$.

107 An accompanying provision expressly negates any effect on the certification provisions of an issuer reincorporating offshore. Act, §302(b). This patchwork provision reflected in part that the Big Four included Global Crossing, a Bermuda corporation, and that scandal-plagued Tyco had reincorporated in Bermuda, as well as prevailing public concern when a score of companies effected such reincorporations. The dominant motive for reincorporating offshore was not to avoid such certification obligations, however, but to avoid taxes.

108 Act, $\S 304$.

109 The provision is simultaneously watered down by giving the SEC authority to exempt issuers as it deems necessary or appropriate. The effect is to create more of a default regulation than a mandatory legal restraint. This makes the provision even more modest than a patch for a problem.

110 Act, $\$ 404$. 
milestone legislation mandating internal financial reporting controls in response to that period's equivalent of the Big Four. ${ }^{111}$ It also duplicates the practice followed by most companies pursuant to perceived mandates emanating from such influential state law cases as In re Caremark Int'l. ${ }^{112}$

Outside auditors must sign off on the assessment, also followed as a matter of practice and generally accepted auditing standards before the Act. ${ }^{113}$ The Act requires compliance programs, document retention policies, and internal investigation procedures. All this has been standard practice. Companies must disclose any significant internal controls changes. To the extent "significant" equates to bearing on the "materiality" of financial statement presentation, this too is a move to clarify what was already required rather than to compel anything new.

Internal controls are an integral component of corporate governance. Neither regulators nor investors should repose too much confidence in their usefulness for insuring compliance with laws or financial reporting requirements, however. Substantial limits on the effectiveness of internal controls have been documented in a wide range of contexts, financial reporting included. $^{114}$

The SEC must promulgate rules requiring annual and quarterly report disclosure concerning whether the company has adopted a code of ethics for senior financial officers and, if not, why not. Changes to ethics codes must be disclosed promptly in current reports on Form 8-K. ${ }^{115}$

These provisions are also inspired directly by Enron. Its board repeatedly waived and made other changes to the Enron ethics code to permit insiders to hold various positions otherwise constituting conflicts of interest. ${ }^{116}$

The provision is modest in the same sense as the have-or-disclose provision concerning financial experts on the audit committee. No code of ethics is required. ${ }^{117}$ But its absence must be disclosed and explained.

111 In that period, dozens of major SEC enforcement actions followed. See Lowell Brown, Caremark, 26 Del. J. Corp. L. 1 (1997).

112698 A.2d 959 (Del. Ch. 1996).

113 See supra, Bus. Law. Ad Hoc Reports.

114 E.g., Statement of Auditing Standards No. 55 ("The potential effectiveness of an entity's internal control structure is subject to inherent limitations"); see Donald C. Langevoort, Monitoring: The Behavioral Economics of Corporate Compliance with Law, 2002 Colum. Bus. L. Rev. 71 (2002); Lawrence A. Cunningham, Internal Controls and the War on Terrorism (manuscript).

115 As with the provision relating to disclosing the absence of a financial expert on the audit committee, this provision reflects a European approach to best practices not required but whose absence must be disclosed and explained. See Bus. Law. supra.

116 Notably, the Act defines the term "code of ethics" as "such standards as are reasonably necessary to promote (1) honest and ethical conduct . . . (2) full, fair, accurate, timely, and understandable disclosure ... and (3) compliance with applicable governmental rules and regulations." "116 The definition makes no distinction between written and unwritten codes. Scenarios raising thorny disclosure issues spring to mind. Must informal policy or norm changes be disclosed on Form 8-K? 
It is possible that adopting policies and codes can promote a culture of corporate compliance and integrity. But it only takes a few rotten apples near the top to spoil the bunch, rendering the personal traits of top leaders far more important than the controls and codes coerced or mandated by law.

Promptly following adoption of the Act, law firms around the country prepared model codes. The risk is to paper over underlying dereliction. This is a common problem of procedure-based regulations. Checking boxes is far easier than assuring honesty.

\section{Insiders}

Two provisions of the Act directly regulating management are direct responses to two perceived injustices widely reported by the media. At the Big Four and other companies in the financial tornadoes following the tele-dot-com meltdown, as stock prices plunged insiders sold shares even as the company pension fund was forbidden under existing federal rules to sell shares held in trust for the benefit of the employees.

To prevent this misalignment from recurring, the Act forbids officers and directors to trade securities received by them as employees when the company's retirement plans aren't allowed to trade. ${ }^{118}$ Violations of this rule call for forfeiture of the profits made to the company without regard to intent. This levels the playing field by bringing a new federal law into alignment with an older one.

Tipping at the federalism balance in corporate law, the Act authorizes derivative lawsuits to recover such blackout profits. ${ }^{19}$ Several details encroach on state law. First, the Act authorizes "securityholders" to maintain actions, while state law is clear that only equity owners have derivative standing (a provision also reflected in the Federal Rules of Civil Procedure). ${ }^{120}$ Second, the Act gives directors a 60-day window in which to respond, whereas most state laws give 90 days and Delaware gives a "reasonable period of time."121 Third, the Act introduces a "diligence" standard to assess director responses, an injection of standards likely to differ from applicable state law standards developed under the doctrines of demand and demand futility. ${ }^{122}$

117 New rules surfaced by the New York Stock Exchange contemporaneously with the Act impose a requirement that listed companies adopt and disclose a code of business conduct and ethics.

118 Act, $\S 306$.

${ }^{119}$ Act, $\S 306(a)(2)(B)$ (suit may be brought "by the issuer, or by the owner of any security of the issuer in the name of and on behalf of the issuer if the issuer fails or refuses to bring such action within 60 days after the date of request, or fails diligently to prosecute the action thereafter") (emphasis added and discussed in text).

120 E.g., Del. Gen. Corp. L. § 327; MBCA § 7.40; Fed. R. Civ. P. 23.1; see Harff v. Kerkorian, 324 A.2d 215 (Del. Ch. 1974), aff'd in part, rev'd in part, 347 A.2d 133 (Del. 1975); Hoff v. Sprayregan, 52 F.R.D. 243 (S.D.N.Y. 1971). Some will applaud the move, but see it as utterly incremental compared to what they have advocated. E.g., Lawrence E. Mitchell, The Fairness Rights of Bondholders, 65 N.Y.U. L. Rev. 1165 (1990); Morey McDaniel, Bondholders and Stockholders, 14 J. Corp. L. 205 (1988).

121 E.g., MBCA $\S 7.42$ (90 days); BTZ, Inc. v. National Intergroup, C.A. No. 11388, slip op. At 8 (Del. Ch. Apr. 7, 1993) ("no "magical period of time exists by which to measure whether the suit was filed prematurely") (quoting Rubin v. Posner, 701 F. Supp. 1041, 1045 (D. Del. 1988)).

122 E.g., Aronson v. Lewis, 473 A.2d 805 (Del. 1984); Grobow v. Perot, 526 A.2d 914 (Del. Ch. 1987), aff'd 539 A.2d 180 (Del. 1988); Levine v. Smith, 591 A.2d 194 (Del. 1991). 
This provision potentially strikes at the heart of the duty of care and business judgment rule, the backbone of state corporate law-though in a narrow context. ${ }^{123}$

More forcibly seizing on traditional state corporate territory, the Act prohibits loans to directors and executives (other than outstanding loans so long as they aren't significantly modified). ${ }^{124}$ Until the Act, state law governed loans to management, using a complex web of checks and balances. While it is a small corner of that state territory, ${ }^{125}$ the Act is both blunt and oblique on the point, suggesting Congressional misapprehension of state corporate law texture.

The loan prohibition is a classic case of overreaction to a few miscreants that is simultaneously underinclusive. The provision is a direct response to the non-accounting corporate scandals at Adelphia and Tyco, both of which made sweetheart loans to insiders, tallying in Adelphia's case more than $\$ 3.2$ billion. They are often used by insiders at late-stage companies, where powerholders know before others that insolvency is around the corner (those at Adelphia, a telecom player, are a likely example).

The Act's flat bar will produce unintended and undesirable consequences of two sorts. First, the ban will drive what would otherwise be legitimate tools of corporate governance to still-legitimate but less optimal ones. Second, they will drive fraudsters to use other tools that remain available, though policed in ways similar to traditional policing of loans.

As to the move to legitimate but suboptimal tools, loans are often tailored bonus schemes, forgiven or modified if executives achieve certain results. In that sense they resemble the incentive features of stock options, except they are better. One reason loans are better than stock options is they have a downside if targets aren't met (the borrower must pay), whereas options expiring worthless pose no penalty.

Another superior characteristic of loans compared to stock options is the objectives are tailored to those under a receiving manager's control, such as sales targets in a division. Stock options are geared to stock prices, over which managers have no control and many lack even indirect responsibility. The most significant difference, however, concerns the accounting.

One difference between stock options and loans to insiders is that loans must be accounted for as notes receivable on financial statements and disclosed as related party transactions in footnotes. Additional reporting is required for loans forgiven or adjusted. Stock option costs need not burden an income statement, disclosure about them tends to be opaque and ignored, and the Act makes no mention of these subjects. ${ }^{126}$ Thus loan-based incentive schemes are more transparent than stock option schemes, yet Congress has outlawed the former and done nothing about the latter.

Additional unintended consequences flow. One result of banning loans will be a shift to other forms of compensation, many of which are far worse from an accounting and governance viewpoint than loans, stock options included. The prohibition encompasses not only cash

123 E.g., Aronson v. Lewis, 473 A.2d 805 (Del. 1984) ("the entire question of demand futility is inextricably bound to issues of business judgment and the standards of that doctrine's applicability").

124 Act, $\S 402$. Also excluded are financial products the company otherwise offers in the ordinary course to its customers (such as financial services company issuing credit cards).

125 See infra text accompanying footnotes $\mathrm{xx}-\mathrm{xx}$.

126 Greed has many motives and explanations (and the pathologies at the Big Four quite a few). Still, many designate stock options as a cancer in corporate America. See John Cassidy, How the Financial System Encouraged Corporations to Go Crazy, The New Yorker (Sept. 23, 2002). 
advances repaid with interest but numerous other innocuous pieces of compensation packages. This will include, for example, split-dollar insurance policies where companies pay premiums to build their cash value through an employee's retirement. On retirement, the company is repaid its invested premiums, with no interest, and the remainder is used to fund continuing premiums during retirement.

Experts characterize these as loans, outlawed by the Act. The emerging solution to the threatened unraveling of this staple benefit component is to denominate them instead as bonuses, with the employer never standing a chance of receiving any repayment. In other words, a ban on loans means likely movement of amounts otherwise extended as credit to managers instead being given gratis. The result is a Congressional backfire. ${ }^{127}$

As for egregious unintended consequences, fraudsters will migrate to other devices, rendering the loan ban underinclusive. Sweetheart loans are one of several standard classes of tricks corporate powerholders play to shovel corporate assets to themselves in derogation of the claims of creditors and shareholders. Equally accessible are procedures for leases on sweetheart terms, extraordinary dividends or redemptions on special classes of stock held closely, asset sales on generous terms and unlimited others. Existing law restricts, but as with loans does not ban, these moves through conflict-of-interest standards, legal capital rules, and fraudulent conveyance statutes. You can expect future fraudsters to move to these devices.

State law restrictions on loans, distributions, and other interested transactions such as leases or asset sales to insiders, balance the protection of shareholders and creditors from powerholder exploitation while allowing legitimate value-adding transactions. Broad rules relating to conflict of interest and duty of loyalty and focused rules concerning reasonably equivalent consideration and capital adequacy apply. Imperfect though these devices are, they lodge execution and judgment power in the hands of those best able to assess transactions, subject to judicial review. The crude broad stroke of the Act's loan ban underscores the prudence of such a course.

Preempting this judgment, reasonably satisfactorily regulated by existing law, is therefore improvident policy unlikely to aid the cause of superior corporate governance. It is instead an instance of reactive regulation. It is ironic, given that the philosophy of much of the rest of the Act pins substantial confidence in concepts of independence and internal control, and yet imposes an outright ban on this slice of corporate affairs where it is precisely those tools that have been used to police it.

The Act leaves the stock option issue unaddressed, even though loans to insiders pale in significance to stock options. FASB has struggled for years to produce accounting rules that faithfully reflect the costs of stock options to shareholders. It has met political resistance at every turn and Congress gives it no help in the Act. Devolutionists could applaud Congressional restraint against enacting accounting rules as federal law. ${ }^{128}$ But the numerous patchwork and codifications the Act pursues show that its reticence on stock options is not the product of this principle.

\section{Disclosure and Accounting}

A number of the auditing and corporate governance issues naturally overlap with matters of disclosure and accounting. The Act contains a few additional provisions that relate more

127 Tracie Rozhon \& Joseph B. Treaster, Insurance Plans of Top Executives May Violate Law, $N$. $Y$. Times (Aug. 29, 2002).

128 See Part III. 
directly to both subjects, including the Act's other silver bullet about how authoritative accounting standard setters will be funded.

\section{Disclosing Corrections}

The first intended upshot of the enhanced auditor-audit committee communication is that financial statements must reflect all "material correcting adjustments" auditors identify. ${ }^{129}$ This means that if auditors discover that line costs have been capitalized or an acquired business's value has been impaired but not adjusted on the balance sheet, these must be disclosed. This incremental reform is intended to curtail managerial temptation to take aggressive positions in the first place and enhance the market's ability to detect miscreants sooner rather than later.

2. Disclosing Off-Balance Sheet Transactions

In another direct swing at the Enron debacle, the SEC must adopt rules requiring quarterly and annual disclosure of off-balance sheet transactions of a significant nature anywhere throughout a company and its related parties. ${ }^{130}$ This is intended to get into disclosure documents in a fuller and clearer way all transactions that could come back to haunt a company even if under a claimed GAAP interpretation they can be excluded from the financial statements proper.

This provision, while important and valuable, is also redundant. Information of that scope and materiality already should be disclosed under existing requirements that financial statements and disclosure fairly present a company's financial condition and that the filing is not false or misleading. This provision clarifies, reinforces and focuses attention on the issue rather than extends it. This is no reform at all.

\section{Pro-Forma Presentations}

The other category of accounting outrage of the late 1990s concerned pro forma accounting. Global Crossing, as noted, led the league in this mischief, sporting a more pervasive use than most of the Big Four (or the hundreds of other users of this financial reporting narcotic). The "as if" numbers prepared by consciously ignoring GAAP are a travesty.

The Act requires the SEC to promulgate rules requiring publicly disclosed pro forma financial data to be presented in non-misleading ways with full reconciliation to GAAP. ${ }^{131}$ These rules are again substantially redundant, however, for companies were always forbidden to publish misleading statements, and the full reconciliation to GAAP was required by the SEC as a practical matter. In this case, the rules are likely to permit continued manufacturing and use of pro forma data that remains misleading in practice.

\section{FASB and Accounting Standard Setters}

There is a silver bullet in the accounting standard setting provisions of the Act, related to the silver bullet of creating the PCAOB. The Act directs the SEC in determining how accounting principles become generally accepted. ${ }^{132}$ The leading standard setter for accounting

129 Act, $\S$.

130 Act, $\S 401(\mathrm{a})$. The language reads as follows:

"all material off-balance sheet transactions, arrangements, obligations (including contingent obligations), and other relationships of the issuer with unconsolidated entities or other persons, that may have a material current or future effect on financial condition, changes in financial condition, results of operations, liquidity, capital expenditures, capital resources, or significant components of revenues or expenses."

131 Act, $\S 401(\mathrm{~b})$.

132 Act, $\S 108$. 
principles since 1973 has been the Financial Accounting Standards Board (FASB). FASB has been funded by the public accounting industry. To continue its standing, the Act requires it (or any other such body) to be funded from issuers of public securities themselves.

Making it clear that the Act does not limit the SEC's pre-existing authority to establish accounting principles and standards applicable to issuers, ${ }^{133}$ the Act permits the SEC to recognize as "generally accepted" accounting principles established by standard setting bodies possessing detailed characteristics, including funding as the Act directs from annual accounting support fees payable by registrants.

In addition, to qualify as a standard setter under this provision, bodies must be private entities serving the public interest and comprised of a majority of persons unassociated with a PCAOB-registered public accounting firm for at least two years. ${ }^{134}$ They must have procedures to promptly consider needed accounting changes by majority vote. They must consider the need to keep standards current and to achieve international convergence. The body must submit annual reports to the SEC.

The net effect of these provisions - the SEC retaining plenary power to promulgate accounting rules while being authorized to recognize only statutory standard setters - is that the SEC may recognize as generally accepted those accounting principles emanating from any source while being able to tell organizations such as FASB that their rules are not generally accepted unless they satisfy the Act's structural directives.

As with the PCAOB, this indirect control over accounting standards is intended to attenuate FASB's relationship to the profession and to bolster its independence. The same issues raised concerning the probable success of the PCAOB apply. ${ }^{135}$

\section{Continuous Disclosure}

The Act enshrines a movement among the market and participants toward a real-time, continuous disclosure system. Companies must disclose publicly on a "rapid and current basis" all material changes in their financial condition or operations, including trends, qualitative information and graphic presentations. ${ }^{136}$ Market participants increasingly demand this swift disclosure and the SEC's adoption of Regulation FD during Levitt's tenure required disclosures made to some be made to all. The SEC was in the midst of rulemaking, when the Act passed, to require more current disclosure on Form $8-\mathrm{K}$ with respect to a wide range of matters As a practical matter, these initiatives substantially hastened the speed and currency of disclosure. Again, the Act more nearly formalizes a practice as federal law than compels much that is new. ${ }^{137}$

\section{E. Enforcement}

An elaborate network of enforcement mechanisms promotes the effectiveness of federal securities regulations. Chief rulemaking and civil enforcement power is vested in the SEC, but

133 The SEC has the authority to define accounting principles pursuant to 15 U.S.C. $\S \S 77 \mathrm{~s}(\mathrm{a})$, $78 \mathrm{c}(\mathrm{b}), 79 \mathrm{t}(\mathrm{a}), 80 \mathrm{a}-37(\mathrm{a})$.

134 The restriction to private bodies excludes state accountancy boards and equivalent bodies.

135 See supra.

${ }^{136}$ Act, $\S 501$, amending 15 U.S.C. 780-6.

137 A final tinkering provision of the Act concerns the timing of disclosing insider trades. Section 16 of the Securities Exchange Act has long required insiders to file reports by the $10^{\text {th }}$ day of the month following the trade. The Act shrinks the time frame to 2 days from the trade. Act, $\S 403$. 
important criminal liability exists with enforcement power lodged in the US Department of Justice. Internal, private and professional enforcement mechanisms supplement these governmental regimes, roles nominally strengthened in the Act's codification of various existing rules.

\section{Whistleblowers}

Under the Act, companies may not retaliate against employees for assisting in internal or external investigations of corporate violations of federal securities or anti-fraud laws. ${ }^{138}$ More redundancy, of course, for the federal whistle-blower statute has always prohibited this. Basic common law rules include a public policy exception to employment-at-will rules that protect even non-contract workers from retaliatory action, including discharge. The Act expressly grants whistleblowers private rights of action for retaliation by a public company, also a formalization of a pre-existing policy right.

\section{Lawyers; Private Enforcement}

The SEC must establish minimum standards of attorney professional conduct that require attorneys to "report evidence of a material violation of securities law or breach of fiduciary duty or similar violation" to the company's chief legal counsel or CEO. If those do not respond appropriately, then the lawyer must report on to the audit committee or any other committee comprised solely of independent directors. ${ }^{139}$

At a literal level, we again see enacting the enacted, but the seemingly simple in this context is potentially quite complex. As for further codifying, state law invariably carries some version of the reporting fraud requirement. State rule language contains sufficient looseness and some interstate variation that competing interpretations and standards are prevalent. In no case, however, are lawyers permitted to simply shut their ears, seeing and hearing no evil. Most lawyers live up to the standard. Hence, the Act does little or nothing meaningful on this point. ${ }^{140}$

On the other hand, numerous open issues arise. First, the Act injects itself into state territory governing the regulation of lawyers and calls on them to report breaches of fiduciary duty, entering the additional state territory of corporate law. Second, unaddressed is the logical limit of granting the SEC this power compared to all other federal agencies before which lawyers practice. Third, the Act ignores, leaving the SEC to hazard into, the deep and perennial conflict between lawyer confidence and disclosure in which disclosure mandates dry up confidence. Fourth, will the SEC properly attend to the distinction between the corporate entity itself and the

${ }^{138}$ Act, § 806, amending 18 U.S.C. ch. 73.

${ }^{139}$ The SEC has always been interested in seeking to regulate lawyers practicing before it, as it has successfully done of accountants practicing before it. Controversy on its interest in regulating accountants erupted in connection with its adoption, in 1998, of Rule 102(e) defining the standard of culpability for accountants exhibiting "improper professional conduct." See Roberta S. Karmel, Accountants' Culpability Under Rule 102(e), N.Y.L.J. (Oct. 29, 1998) (detailed history from former SEC Commissioner involved in earlier such debates). The legal profession was deeply concerned about the exercise of SEC authority over accountants. E.g., Report of the Task Force on Rule 102(e) Proceedings: Rule 102(e) Sanctions Against Accountants, 52 Bus. Law. 965 (1997). It is even more concerned now.

140 See David J. Sorin, Kristina K. Pappa \& Emilio Ragosa, Sarbanes-Oxley Act: Politics or Reform? Statute's Effects Are Not as Profound as Legislators Would Have Us Believe, N.J.L.J. (Sept. 2, 2002) ("most members of the securities bar ... have always performed their duties in a proactive, ethical and impartial manner. Nonetheless, formal rules will provide guidance ..."). 
corporation's shareholders? Fifth, there is no distinction in the Act between representation of an organizational client, as under state ethics rules, and individuals within the organization (or committees or other juridical agents). We could go on. This is a blunt instrument as yet, raising numerous subtle issues. ${ }^{141}$

Setting all this aside, under the Act a lawyer's duties do not change, though enforcement for violations is entrusted now to the SEC as well as to state professional disciplinary bodies. Lawyers may well have more to fear from the SEC than state ethics committees, but the underlying obligation is dimly varied by the Act.

For private securities fraud lawsuits, the Act lengthens statutes of limitations (to the earlier of two years from discovery or five years from violation). ${ }^{142}$ This incrementally broadens the policing power of the private securities litigation bar. A rich debate centers on the role of this group. The broad issue is whether they add or subtract value from corporate America and its shareholders. Compared to other reforms that could have been taken, this one is modest.

Major possible reforms include reversing those made in 1995's Private Securities Litigation Reform Act, chiefly raising the bar for pleading fraud and identifying a case's lead plaintiff and lead counsel; as well as the follow-on Securities Litigation Uniform Standards Act of 1998 (SLUSA) restricting claims to federal rather than state court. None of the PSLRA/Slush's provisions are touched in the Act. Thus those who believe the plaintiff's bar plays a useful disciplining role in corporate governance can applaud the modest measure of extending the statute of limitations, while those more skeptical can breathe a sigh of relief that no more relaxation's were made. ${ }^{143}$

\section{The SEC}

Putting more pressure on the watchdog function of the SEC, the Act requires the SEC to review disclosures, including financial statements, regularly and systematically, giving every company a once-over triennially. SEC review must be more frequent for larger and newer companies on the one hand, and those having made material restatements or experienced significant stock price volatility on the other. Combined, the effects are akin to increasing the number of IRS audits, promoting compliance with what is largely a voluntary compliance system.

Carrying potentially significant enforcement effects, the SEC's power rises, giving it plenary enforcement power on all aspects of the Act, including pursuing all penalties and remedies, such as payment freezes and power to bar people from serving as officers or directors of public companies. The actual significance of these changes will be determined by how the SEC uses this power.

${ }^{141}$ For a textured assessment of this federal entree into state regulation of lawyers, see Simon Lorne, Sarbanes-Oxley: The Pernicious Beginnings of Usurpation?, Wall St. L. (Sept. 2002).

142 Act, $\S 804$.

143 Related to private litigation, but a bit beyond questions of accounting and corporate governance, the Act also amends the Bankruptcy Code to provide that debts of individuals from judgments or settlements of securities law or fraud are not dischargeable in bankruptcy, keeping more resources available for private remedy. Act, $\S 803$, amending 11 U.S.C. 523(a). 


\section{Criminal Offenses and Penalties}

New criminal offenses and increased penalties are imposed. ${ }^{144}$ In another direct response to the Enron shenanigans practiced by Arthur Andersen during federal investigations, the Act increases criminal penalties for altering documents. "The "knowing"146 or "corrupt"147 destruction, alteration, or falsification of records with intent to frustrate federal investigations yields fines and imprisonment of up to 20 years. Auditors are required to maintain records and workpapers for five years. In the same responsive spirit, the Act creates a new offense for "securities fraud schemes"148 and for "attempts.",

In general, violations result in criminal and civil liability, with the maximum fine rising from \$2.5 million to \$25 million. Increased sanctions apply to conspiracies, attempted fraud, and mail and wire fraud, all up to 20 years. Increased penalties also apply for ERISA violations, from 1-10 years in jail and up to $\$ 500,000$ fines. "Knowing" violations of the CEO/CFO certifications cost up to 10 years and $\$ 1$ million and "willful" ones yield up to 20 years and $\$ 5$ million.

Whether these measures are likely to have any effect on the inclination of managers to cheat requires a theory of deviance or criminality. To the extent fraudsters or criminals are rational economic actors inclined to calculate cost-benefit analytics before committing legal transgressions, the provisions certainly will add deterrence. Those who believe cheats are cheats may applaud the signal but lament its unlikely impact. Either way, these penal increases innovate and change in contrast to much of the rest of the Act's contentment to federalize practice, custom, standard, regulation or state law.

As for the amounts, increasing monetary penalties from $\$ 2.5$ million to $\$ 25$ million looks tough. On the other hand, since the levels were last set, the value of a million dollars has changed. The change's significance is not in terms of simple inflation measured by such indices as the consumer price level. Rather, the baseline should be average compensation of those being addressed. Fines are increased tenfold. Executive compensation has risen vastly more. On this score, the Act is a catch-up, at best. ${ }^{150}$

More importantly, fines other than those due to criminal behavior are likely to be covered using D\&O insurance a company pays for. Corporate authority to provide insurance coverage is also a subject of state rather than federal law and Congress chose not to encroach on this area. This decision was made despite advocacy by Treasury Secretary O’Neill encouraging it. ${ }^{151}$

144 Apart from changes mentioned in the following text, the Act directs the US Sentencing Commission to review Sentencing Guidelines for white collar crimes to assure they reflect the spirit of the Act and gravity of offenses. See infra.

${ }^{145}$ Act, $\S$ 802, amending 18 U.S.C. 1501; Act, § 1102, 18 U.S.C. 1512.

146 Act, $\S 802$.

147 Act, $\S 1101$.

148 Act, $\S 807$.

${ }^{149}$ Act, $\S 902$.

150 A possible reform would calibrate fines to company size, though the Act, as previously, permits judicial discretion to specify fines taking this factor into account (up to the statutory maximum anyway).

${ }^{151}$ See William H. Widen, Enron At the Margin (manuscript, 2002, copy on file with the author) 
In a final long overdue move, the Act alters the standard of desecration the SEC must show to bar officers and directors from future service at SEC registrants. The previous standard set the bar at "substantial unfitness." The new bar is "unfitness." "152 One might have been forgiven for thinking that an officer or director who was unfit for service was, well, unfit for service. The Act makes this common sense law.

\section{Securities Analysts}

Leading villains in the tele-dot-com fallout, securities analysts face a sideswipe under the Act. In a well-functioning world, these intense observers of corporate performance and reporting should be part of the enforcement mechanisms. That is, they should wield a disciplining influence on management and financial reporting. Alas, during the salad days of the late 1990s, they were anything but.

The SEC (or the stock exchanges if it directs) must adopt rules restricting prepublication clearance of research reports by investment bankers, of supervision of analysts by investment bankers, or pressure or retaliation by bankers against analysts; creating black out periods on reports surrounding public offerings underwritten by the analyst's firm; and disclosing remaining conflicts the analyst knows or should know about. ${ }^{153}$

Most of these provisions were developed in Summer 2001 privately by the securities industry and member firms in the wake of the reported dereliction of this community of cheerleaders for public offerings. ${ }^{154}$ Some of these reforms were the result of pressures brought to bear by state attorney generals, led by New York's Elliot Spitzer. Prudence dictates exercising continued skepticism about the veracity and objectivity of reports emanating from this segment of the investment business, ${ }^{155}$ but it was politically impossible for Congress not to tell the SEC to do something. ${ }^{156}$

\section{F. Studies}

An entire section of the Act is devoted to prescribing studies and reports, along with a few required in scattered other sections. ${ }^{157}$ The Act directs nine studies to be conducted, by the

${ }_{153}^{152}$ Act, $\S 305$, amending 1934 Act $\S 21(d)(2)$.

153 Act, $\$ 501$, amending 15 U.S.C. 78a (by adding Sec. 15D).

${ }^{154}$ Securities Industry Association, Best Practices for Research (June 2001); Gretchen Morgenson, Wall Street Firms Endorse Ethics Standards for Analysts, N.Y. Times (June 13, 2001); Bloomberg News, Morgan Requires Analysts' Disclosure, Wall St. J. (Aug. 25, 2001); Charles Gasparino and Jeff D. Opdyke, Merrill Alters a Policy on Analysts, Wall S. J. (July 11, 2001); Susanne Craig, Credit Suisse Limits Holdings Of Its Analysts, Wall S. J. (July 25, 2001); Staff Reporter, Edward D. Jones Puts Limits on Stock Owned by Analysts, Wall St. J. (July 12, 2001).

155 See Securities and Exchange Commission Press Release, "SEC Cautions Investors About Analyst Recommendations," Release No. 2001-66 (June 28, 2001); Securities and Exchange Commission, "Investor Alert: Analyzing Analyst Recommendations" (July 13, 2001).

${ }^{156}$ Put more realistically, the SEC sought and got a statutory mandate to do something. See Karmel, supra.

157 The placement of the study requirements suggests that some were pet projects of particular proponents of the Act. For example, one provision establishes a disgorgement protocol for illgotten gains to fund investor restitution. Act, § 308. Accompanying this is express SEC authorization to accept "gifts, bequests, and devises of property, both real and personal, to the US for [the] disgorgement fund." Perhaps the sponsoring Member of Congress has private 
SEC and the Comptroller General, with additional direction to the US Sentencing Guidelines Board. Studies are to be completed within six months to one year after enactment (meaning February or August 2003) and typically call for a report to be submitted to designated committees of Congress. Some call for regulatory and legislative recommendations or enactment or amendment of rules and regulations as the study indicates. ${ }^{158}$

\section{Audit Industry Consolidation}

The first mandated study requires the Comptroller General to examine the factors producing auditing industry consolidation since 1989 and consolidation's consequences for capital formation and securities markets. ${ }^{159}$ It calls for offering solutions to observed problems, including how to increase industry competition and member numerosity. ${ }^{160}$ How any problems affect issuers is also sought, as to costs, quality, independence, and alternatives, along with identifying any regulatory impediments to competition, federal or state.

\section{Investment Banks and Financial Reports}

The Comptroller also must study the role investment banks and financial advisors play in assisting issuers in earnings manipulation or financial reporting obfuscation. ${ }^{161}$ This study singles out by name Enron and Global Crossing, seeking learning concerning the role the banks and advisors played in Enron's collapse (and use of special purpose entities (SPEs) and derivatives) and Global Crossing's failure (and capacity swaps). More generally it seeks assessment of the role of these professionals in creating and marketing deals designed solely to

knowledge, but the prospects for such a fund do not seem overwhelming. Even so, accompanying both provisions is a further requirement that the SEC study disgorgement practices, discussed further below. The sponsor of that provision is House Capital Markets Subcommittee Chairman Richard H. Baker (R--La.) who rhapsodized that "with my FAIR funds proposal, House Republicans have insisted that defrauded investors be treated with fairness and have a chance for restitution of their losses. ... [and] will go a long way toward rebuilding small investors' faith that the American dream, based in fairness to all, is still possible." President Signs Sweeping Corporate Reform Bill Into Law, Sec. Litig. \& Reg. Rptr. (Aug.14, 2002) (Vol. 8; No. 5; Pg. 4).

158 When this article is published, some of the studies will have been completed while others are ongoing. The studies may produce or lead to "reforms" fairly characterized as "sweeping" or "far-reaching." Whether they do does not change the more accurate characterization of the Act as modest.

${ }^{159}$ Act, $\$ 701,15$ U.S.C. 7201. I can offer two suggestions off the top of my head as bookends to the question: the collapses of Laventhol \& Horwarth in 1990 (then $7^{\text {th }}$ largest of 8) and Arthur Andersen in 2002 (then $4^{\text {th }}$ largest of 5) both due to regulatory and law enforcement activities.

${ }^{160}$ Notable potential competitors or entrants are American Express (AmEx), already a substantial industry participant, and McGladery Pullen and Grant Thornton, significant players but as yet dwarfs compared to the remaining big four (and AmEx).

161 Act, $\S 705$, amending 15 U.S.C. 7201. A typo appears in the original official publication of the Act. In that version, the Comptroller is to study "the rule of investment banks and financial advisers (1) in the collapse of Enron . . . and (2) in the failure of Global Crossing." Two Freudian interpretations appear: (a) that bankers and advisers "ruled" over those debacles and (b) that they are now going to be "ruled." [The typo was removed in the formal statutory codifications in the United States Code.] 
enable revenue stream manipulation, moving liabilities off-balance sheet without also reducing risk, and other obscuring mechanisms.

\section{Mandatory Audit Firm Rotation}

Building on the Act's federal version of the rule mandating rotation of audit firm partners, the Act instructs the Comptroller to study and review the effects of the stronger medicine requiring mandatory rotation of audit firms. ${ }^{162}$

4. Rating Agencies

The SEC must study the role and function of credit rating agencies in securities market operations, including concerning issuer evaluation, importance, accuracy, barriers to entry into the business, information dissemination measures, and any conflicts and how to ameliorate them. ${ }^{163}$

\section{Off-Balance Sheet Transactions}

The SEC must study issuer filings and disclosures to ascertain the extent of off-balance sheet transactions and the frequency of using special purpose entities (SPEs). ${ }^{164}$ That study is also to assess whether financial statements reflect the economics of these transactions when prepared in accordance with generally accepted accounting rules. ${ }^{165}$ The follow-on report to Congress (also to be directed to the President) must assess whether GAAP requires consolidation for sponsored SPEs when the sponsor bears a majority of their risk and rewards and any recommendations to improve transparency in SPE and off-balance sheet reporting.

\section{Aiding and Abetting}

The SEC also must study its enforcement actions over the past five years to determine the number of gatekeepers having aided and abetted securities law violations without sanction as primary violators as well as those found liable as primary violators. ${ }^{166}$ This study is intended to appraise the significance of the Supreme Court's decision in Central Bank of Denver construing federal securities laws as insulating securities professionals from liability as secondary offenders. ${ }^{167}$ Required details include sanctions or censure imposed, any multiple violators, and payments made.

\section{Fraud Susceptibility; Disgorgement}

A separate SEC study of enforcement actions requires, for the same five-year period, identifying financial reporting contexts most susceptible to fraud, "inappropriate manipulation," or earnings management. ${ }^{168}$ Another separate enforcement action study calls for the SEC to

162 Act, $\S 207$.

163 Act, $\S 702,15$ U.S.C. 7201.

164 Act, $\S 401,15$ U.S.C. 7261.

165 The Act in this context uses the phrase "generally accepted accounting rules" (emphasis added), while using the standard phrase generally accepted accounting principles (GAAP) in the succeeding complementary provisions. Succeeding provisions use the term GAAP "or the rules of the Commission," suggesting an intentional distinction between a broader notion of rules and GAAP.

166 Act, § 703, 15 U.S.C. 7201. Gatekeepers are "securities professionals," defined as "accountants, public accounting firms, investment bankers, investment advisors, brokers, dealers, attorneys, and other securities professionals."

167 Central Bank v. First Interstate Bank, 511 U.S. 164 (1994).

168 Act, § 704, 15 U.S.C. 7201. Modifying the word "manipulation" with the word "inappropriate" is another clue of the Act's modesty, not its far-reaching "reform." 
examine civil penalty and disgorgement recoveries to identify contexts where recoveries can be used to provide future investor restitution. ${ }^{169}$

\section{Punishment}

The Act directs the US Sentencing Commission to review and if necessary amend the Federal Sentencing Guidelines. ${ }^{170}$ Areas singled out for attention are precisely those raised by the Big Four and Andersen's role in them: obstruction of justice, ${ }^{171}$ financial fraud, ${ }^{172}$ and securities and accounting fraud. ${ }^{173}$ Emphasized are the sufficiency of penalties to deter and punish.

In the case of obstruction of justice, emphasis is also laid on ensuring that the enhancements and specific offense characteristics are adequate in cases just like those arising in the Enron/Andersen situation: destroying, altering or fabricating evidence by those in positions of trust or involving large amounts of evidence or particularly probative evidence or involving substantial planning. ${ }^{174}$ In the case of the financial, accounting and securities fraud offenses, emphasis is placed on assuring that the Guidelines reflect their "serious nature."175

9. Comparative Accounting: US GAAP v. UK GAAP

Finally, the Act calls for a study to assess the comparative advantages of a system of accounting based on a foundation of principles rather than rules. ${ }^{176}$ This is certainly the most open-ended of these potentially ambitious studies. Numerous questions arise that can't be addressed. But the broadest one can be mentioned: is the premise accurate, that US GAAP is more rules-based than principles-based or at least as compared to UK GAAP? ${ }^{177}$

US GAAP is a mix of principles and rules. FASB has articulated a series of broad principles constituting its spirit and bedrock (issuing 7 "Statements of Financial Accounting Concepts"-SFACs - since 1973) against which more detailed rules are gauged (through 2001 FASB issued 144 "Statements of Financial Accounting Standards"-SFASs — and thousands of other detailed "Interpretations" and "Technical Bulletins"). How a principles-based compilation would look is unclear as yet, but does it seem sensible in principle to scrap the SFASs and other detailed promulgations and have resort solely to the SFACs? ${ }^{178}$

${ }^{169}$ Act, $\S 308$.

${ }^{170}$ Act, $\S \S 805 ; 905 ; 1104$.

${ }^{171}$ Act, $\S 805$.

172 Act, $\S 905$.

173 Act, $\S 1104$.

174 Act, $\S 805$.

175 Act, $\$ 805$ \& 905.

176 Act, §108(d).

177 It seems more accurate, though still a stretch, to say that UK auditing standards are more principles based and US auditing standards more rules based. Carol A. Frost \& Kurt P. Ramin, International Auditing Differences; Comparing the U.S., United Kingdom and Germany, $181 \mathrm{~J}$. Acct. vol. 4, at 62 (April, 1996). But auditing standards and accounting standards are not the same.

178 Suppose the study finds UK GAAP and a principles oriented approach superior. What are the odds that the discovery would be applied in analogous contexts, such as corporate governance and securities regulation, where the Act uses the most detailed and precise rulesbased approach imaginable. (The chances are nil.) 
The studies serve many functions in the overall context of the Act. First, they will produce interesting data for analysis. Second, they may have been included at the request of legislators seeking stronger medicine. The results may support those legislators.

Third, the studies constitute continuing and direct Congressional oversight of the subjects studied. In the case of studies directed at particular industries, this means the spotlight remains on high wattage. That should stiffen spines. It certainly will aid the original momentum of the PCAOB, as noted, as well as fortify FASB.

Fourth, long after direct Congressional interest has dimmed, the studies will percolate throughout the corporate governance and accounting communities. They will be on hand as responses when the next crisis hits accounting and corporate governance. No one can say when that will be, but the question is only when, not if - despite or given the Act's "sweeping" and "far-reaching" "reforms."

\section{Broader Assessment}

The Act deserves a B-, respectable, but surprisingly low given the attention showered on it by the press, law firms, executive suites, investor groups, and the public. Recapitulating the highlights, the Act (a) contains the silver bullet of restructuring and refunding of auditing and accounting standard setters, carrying hope but no assurance; (b) codifies as federal law existing practice, rules, regulations, and laws; ${ }^{179}$ and (c) makes other changes that are either modest (such as have-or-disclose rules for financial experts on audit committees and codes of ethics and restricting insider stock sales when company pension plans are restricted) or risky (prohibiting insider loans).

The dog that didn't bark is striking: the Act does nothing about stock option accounting. ${ }^{180}$ Congressional reticence on accounting for stock options as an expense in the income statement can be explained by the Act's central codifying characteristic: no such extant rule exists, so there was nothing to codify. This reticence illuminates the Act's implicit philosophical compromise: it mostly federalizes dozens of existing rules, but mostly refrains from federalizing anything new.

A longstanding debate considers whether federal or state regulation of corporate governance is fairer and more efficient, a debate long thought settled. Several provisions of the Act addressing matters of internal corporate affairs indicate that the debate remains vital, but far fewer changes than easily could have been the case (and might yet).

179 To summarize: ignorance is not recognized as an excuse for CEOs and CFOs, audit committees have faced heightened duties and independence requirements by the stock exchange and SEC rules for decades, the Levitt reforms prohibited auditors from doing the services the Act restricts (and most of the remaining big auditors are already out of those businesses anyway); lawyers have been required to report fraud up the ladder and resigning if uncorrected; the securities industry already cracked down on its analysts under pressure from state attorneys general.

180 Neither the House nor the Senate bill that became the Act ever addressed stock option accounting, though a separate bill offered by Sen. Carl Levin (D. Mich.) did. See Marilyn Geewax, Accounting Reform Faces Key Vote in Senate Panel, Cox News Service (May 20, 2002). 
The Act displays conscientious concern for federalism issues. True, the Act preempts state law in various contexts (it bans loans, specifies audit committee duties, authorizes certain derivative suits, regulates and authorizes federal regulation of securities and corporate lawyers). At the same time, it shows federal deference. For example, concerning public accounting firms not registered with the $\mathrm{PCAOB}$, the Act advises state regulators to make independent assessments of required standards that may differ from those the PCAOB imposes for public companies. ${ }^{181}$ The studies stay the federalism hand.

\section{A. Retrospective}

It is impossible to prove that the enactments would or would not deter or prevent repetition of the scandals they are designed to deter or prevent. But a look back at Part I's summary of the Big Four compared with the content of the Act suggests that the broader cultural features that promoted the scandals are caused by forces not amenable to regulation, including investor exuberance, a periodic economic boom that produces economic hallucinations and mass stock market psychosis.

Assume Global Crossing were created several years on, after the tele-dot-com burst and after the reforms contained in the Act took effect. Would it likely have attracted the capital it did? What, if anything, would have impaired the accounting deceptions it practiced? The Act? What, if anything, might rejuvenate temptation? Market madness? Which is likely to dominate, the Act or madness?

Of our hypothetical future Global Crossing: The company had certified financials, attested to by the CEO and CFO alike along with all other senior managers and the board. An audit committee held a regular dialogue with outside auditors, discussing internal controls. An outside auditor conducted test audits of the financials and the controls and issued unqualified opinions. All pro forma accounting disclosure was carefully accompanied by disclaimers as to its reliability. The audit committee hired outside advisors, lawyers were obligated to report detected fraud up the chain of command, whistleblowers would have been protected. The SEC, the PCAOB and other regulators watched carefully, while securities analysts gave their own opinions.

But suppose also the market was excited. Pipedreams were believed in. The laws of economics were widely advertised as having changed. A whole new era dawned, people everywhere said and believed. None of those old rules made sense in this bold world, reborn. A born again tele-dot-com boom - with different names, nuances, and players - induced billions of dollars, then trillions, into those businesses and the go-go days are here again.

Which force will be the stronger, the regulation or the psychology? Most likely, if history is permitted to be a guide, emotions will beat governance every time. ${ }^{182}$ Put forensically, the market exuberance of the late 1990s and early 2000s did not arrive out of the blue, but constituted repetition of a pattern seen repeatedly in world financial history. Regulatory breakdown is far less likely than rationality breakdown the cause of schemes such as Global Crossing or Enron.

While reporting, supervisory, and standard-setting roles are critical, and must be tended, they are not a final fix to forfend financial fraud. For that, a deeper investor and market rationality is required that history repeatedly teaches is unlikely to arrive. The best the regulator can hope for is deterring at the margins, not preventing all perpetration. Modest acts, such as the

${ }_{181}$ Act, $\S 209$.
For skeptics, see Charles McKay, Popular Delusions and the Madness of Crowds. 
Act, may be exactly what is called for in the face of the crisis of the Big Four, which may explain the Congressional modesty pervading the Act.

\section{B. Congressional Hedging}

Congress and President George W. Bush must know the Act is hardly a feat of boldness. ${ }^{183}$ Perhaps they recognize that the Big Four scandals were discrete and idiosyncratic dysfunction, not characteristics of omnipresent deception in corporate America. After all, more than ten thousand publicly traded US corporations are in ship shape, well-governed, faithfully accounted for, independently audited, meeting substantial payrolls, and generating shareholder profits. But they also knew that constituents wanted action, eyeing these failures after the value of their investment funds - built for dreams concerning first-home purchases, educating children, enjoying retirement, and taking trips around the world - shrank from Dow 12000 to Dow 8000 (and less).

The sensible result may be the package of simple steps to federalize existing rules and norms, with fanfare, coupled with the study steps, that will determine whether the judgment of basic soundness is correct. ${ }^{184}$ If they discover unsoundness, from the studies or otherwise, authentically rather than rhetorically sweeping reforms may be warranted. The studies are a useful mechanism, as noted, to prolong the sense that the Act is designed to stiffen spines. Absent such a response, those it regulates - particularly those addressed in the studies such as investment banks, financial advisors, rating agencies, auditors, and accountants - have much to fear as continuing candidates for legislative reform.

\section{Prospective}

Among the standouts for inclusion in the category of continuing candidates for reform that would be sweeping are those already suggested: restoring the Glass-Steagall Act segregation of commercial from investment banking; overriding Central Bank of Denver to expose securities professionals to aiding-and-abetting liability; or revisiting the PLSRA/SLUSA to recast the deterrence balance between frivolous and meritorious securities fraud lawsuits. ${ }^{185}$ Apart from these reversing options, two forward-looking innovations are worth a few more words, one concerning accounting and one corporate governance.

Both areas traditionally give substantial deference to non-federal regulation. In accounting's case, principles have been developed by private standard setters, with SEC oversight for public companies, which the Act now reins in by restricting the manner of their funding and the processes employed. In corporate governance's case, state corporate law has been the principal source of authority, though as with accounting, securities law and regulation

${ }^{183}$ Numerous heading designations in the Act reveal a conscious sense of incrementalism. E.g., Title IV ("Enhanced Financial Disclosures") (emphasis added); Title IX ("White-Collar Criminal Penalty Enhancements Act of 2002") (emphasis added); Act, § 402 ("Enhanced Conflict of Interest Provisions") (emphasis added); Act, $\S 408$ ("Enhanced Review of Periodic Disclosure by Issuers") (emphasis added).

184 Senior staff members of the Senate Banking Committee, where the legislation originated and which shepherded it through Congress, responded to the groundswell of concern triggered by the repeated description of the Act as a "sweeping reform" by advising constituents to "cool their heals," for the Act's architecture "needs time to work." Barbara A. Rehm et al., Flash Points, Am. Banker (Sept. 27, 2002), at 4.

185 Parallel debates are ongoing among the US Judicial Conference relating to regulating class actions in ways that move them to federal rather than state court. 
plays an important overriding function, even as it nominally restricts itself to matters of disclosure and timing. Nothing in logic or law prevents Congress from changing both.

1. Across the Pond: Making Accounting Law

Congress could vest the origination and review authority for accounting entirely in the SEC or other federal agency. This proposal was frequently made in the late 1960s and early 1970 s amid last generation's battle with exploding accounting scandals. ${ }^{186}$ It would relegate to secondary authority all other pronouncements from anointed bodies such as FASB and the AICPA, to mere commentaries.

Congress only tips at doing so in the Act. FASB remains the chief accounting standardsetter, though the Act changes its funding and imposes procedures (FASB already pretty much follows what the Act prescribes). Likewise, the Act creates the PCAOB and directs its funding and vast aspects of its mandate and operations. But still those bodies are the standard setters, even as the Act states that its provisions do not restrict the SEC's extant power to promulgate accounting and auditing standards.

The truly "sweeping reform" would be to abolish the FASB and the PCAOB and anything like them and repose all power to set accounting and auditing standards in the SEC itself. This may become necessary or provident pending results of the Act's mandatory study examining the comparative virtues of an accounting system based on articulation of principles rather one anchored in detailed rules.

What will be done with this study of comparative accounting is not clear. If the report concludes that the UK model is superior, the SEC could presumably adopt it. But under the regime left in place but tinkered with, FASB would have a strong say in the process. A tug-ofwar situation endures. The tug-of-war may be desirable as a laboratory for standard incubation, study and debate. But it is by no means necessary, as the UK model indicates.

2. Across the Channel to Civil Law

On this side of the Channel, a grand common law tradition has been lost in the historical evolution of fiduciary duty for corporate officials. Deeper mandates of an earlier era have died. Traditional duties were colorfully expressed in such powerful language as that used by the great early $20^{\text {th }}$ century jurist Benjamin Cardozo. He characterized business law's fiduciary duty as entailing the punctilio of an honor the most sensitive, declaring that among business fiduciaries it is not the morals of the marketplace that govern but the morality of trust and faithfulness.

In today's corporate world, the legal bar has been set far lower, lower than medium height. Consider a leading case from Delaware, the country's leading exponent of corporate law jurisprudence. The board of the Walt Disney Co. lavished exorbitant compensation on CEO Michael Eisner's close friend Mike Ovitz, a Hollywood talent scout. Ovitz got some \$140 million for about a year's retention that involved virtually no work. And they all got away with it.

The Delaware Supreme Court gave a short sermon on good corporate governance. The sermon emphasized the distinction between the bare minimum that Delaware law requires and what the courts there expect of directors. Here is what Chief Justice Norman Veasey told corporate America in February 2000, the month before the tele-dot-com party ended: ${ }^{187}$

186 See Lawrence A. Cunningham, Sharing Accounting's Burden: Business Lawyers in Enron's Dark Shadows, 57 Bus. Law. (Aug. 2002), at n.100.

${ }^{187}$ Brehm v. Eisner, 746 A.2d 244 (Del. 2000). 
This is potentially a very troubling case on the merits. It appears from the Complaint that: (a) the compensation and termination payout for Ovitz were exceedingly lucrative, if not luxurious, compared to Ovitz' value to the Company; and (b) the processes of the boards of directors in dealing with the approval and termination of the Ovitz Employment Agreement were casual, if not sloppy and perfunctory. From what we can ferret out, the processes of the [boards] were hardly paradigms of good corporate governance practices. Moreover, the sheer size of the payout to Ovitz, as alleged, pushes the envelope of judicial respect for the business judgment of directors in making compensation decisions. Therefore, both as to the processes of the [boards] and the waste test, this is a close case.

But our concerns about lavish executive compensation and our institutional aspirations that boards of directors of Delaware corporations live up to the highest standards of good corporate practices do not translate into a holding that these plaintiffs have set forth particularized facts excusing a pre-suit demand under our law and our pleading requirements.

The gap between what Delaware law requires and what constitutes good corporate governance is enormous. Why should that be the case? The intelligent investor is alert for indications that a group of managers is surpassing or slipping under the low legal bar. Why can't judges be?

Managers exuding trust and confidence go beyond the bare bones of modern corporate fiduciary obligation. They operate at the deeper roots, the prevalent mandate imposed in some other areas of fiduciary obligation such as among lawyers, physicians, and clergy. In these professions stress is laid on the need for preserving confidences and secrets, zealousness, safeguarding client property, as well as competence, diligence, and candor. Why shouldn't the same dictates and aspirations apply to corporate senior officers and boards of directors?

Worse, even if the substantive gap endures, where is the judicial hortatory urging managers to narrow it? In other words, let's agree that Cardozo wrote his lofty opinions in a different era and that our era cannot sustain those strictures. The hortatory value of fiduciary standards remains significant. But, on the Delaware Supreme Court at least, that too is gone. ${ }^{188}$ The Disney debacle is representative of that court's judicial expressions in the face of revulsion-deference, toleration.

The Big Four were actively volcanic as the Chief Justice penned those words, though it would be another year before they erupted as revelations of precisely the sort of lavishness and laxity that characterized the Disney board, condoned by the leading corporate law court in the country. Stronger medicine may be needed, and it may be on the horizon. Delaware should take heed, and the lead, for Congress may have to if it doesn't.

${ }^{188}$ Boards of directors, executives and managers are fiduciaries for their corporations and shareholders. The principal justification for this designation is that investors entrust capital to their care and management. They separate themselves from control. The investment constitutes an ownership interest in the corporation, a claim on its assets. That separation of ownership from control requires owners to repose trust and confidence in these corporate officials.

In exercising business judgment, officials must advance the corporation's interests, with the shareholder's interest ranking first, and neither their self-interest nor the interests of other constituencies ranking ahead of that. A wellspring of duties flow from the fiduciary obligation, including undivided loyalty and avoiding conflicts of interest, plus prudence and candor. 
Congress may know next-to-nothing about corporate law (suggested by the Act's crude ban against loans and creation of unorthodox derivative suit rules to recover pension blackout profits), but when Delaware courts fail to use tools at their disposal to police managerial opportunism, Congress may have to do something, perhaps explaining the Act's entry into the state law field, oblique, blunt and narrow as it is. There is precedent in civil law for national legislative establishment of professional standards for business executives. Nothing in law or logic, only politics (and possibly wisdom), prevents it on this side of the Channel.

\section{Conclusion}

As noted, there are numerous senses in which the Act is sweeping - the number of topics it touches, groups it blames-but not in the sense the President, SEC Commissioners, Members of Congress and the press meant to convey when they used the term. There is a final sense in which the Act is undeniably sweeping: the Act appropriates to the SEC additional funds for 2003 to carry out the Act totaling $\$ 670$ million-against an original appropriations budget for 2003 that totaled \$467 million and for 2002 that totaled \$438 million. ${ }^{189}$

The Act is an achievement, perhaps a political/legislative masterstroke. But apart from its silver bullet (funding of auditing oversight board and accounting standard setters), the achievement is not due to anything fairly characterized as "sweeping" substantive "reform." It is not major "reform," but patches and codifications and further study. It is a restatement with the force of federal law.

But the rhetoric accompanying it, echoed dutifully throughout American power centers, will on its own stiffen spines throughout corporate America, promote the ability of those with integrity to deter (perhaps educate) those lacking it and, thus, to provide underlying fairness on which public investors may justifiably rely and in which they may place earned trust and confidence.

The masterstroke is a page from the broader book of responding to national crisis too large to control in fact. In Britain facing the German bombardment of London amid World War II, the government lofted noisy radar interference all around the capital, a show of determination and signal of doing something which had no technical effect on the bombing but some psychological effect on the bombers. The Act is loud, but not deafening; non-trivial, but not more far-reaching than any reforms since FDR. It just might work. Maybe it deserves a $\mathrm{B}+$.

${ }^{189}$ See Testimony Concerning Appropriations for Fiscal 2003, by Harvey L. Pitt, Chairman, U.S. Securities \& Exchange Commission, Before the Subcommittee on Commerce, Justice, State, and the Judiciary, Committee on Appropriations, United States House of Representatives (April 17, 2002) (available at http://www.sec.gov/news/testimony/041702tshlp.htm). Aggregate additional 2003 appropriations in the Act are $\$ 776$ million, of which $\$ 108.4$ million is directed to responding to the terrorist attacks of September 11,2001. Although a billion dollars isn't what it used to be, a modified version of the late Senator Everett Dirksen's quip from the 1960's may be apt: a half billion here and three-quarters of a billion there, and pretty soon we're talking about real money (if rhetorical reform). 